\title{
Marine mammal occurrence and ocean climate off central California, 1986 to 1994 and 1997 to 1999
}

\author{
C. A. Keiper ${ }^{1, *}$, D. G. Ainley ${ }^{2}$, S. G. Allen ${ }^{3}$, J. T. Harvey ${ }^{4}$ \\ ${ }^{1}$ Oikonos, PO Box 979, Paradise Valley, Bolinas, California 94924, USA \\ ${ }^{2}$ H. T. Harvey \& Associates, 3150 Almaden Expressway, Suite 145, San Jose, California 95118, USA \\ ${ }^{3}$ Point Reyes National Seashore National Park Service, Point Reyes, California 94956, USA \\ ${ }^{4}$ Moss Landing Marine Laboratories, 8272 Moss Landing Road, Moss Landing, California 95039, USA
}

\begin{abstract}
The California Current System (CCS), a highly variable eastern boundary system, supports a rich marine mammal fauna. Variation in local coastal upwelling, coupled with larger scale processes (El Niño/La Niña) affects the productivity and distribution of marine species at all trophic levels. Herein, we present an analysis of the occurrence patterns of marine mammals in the central CCS and relate these patterns to changing ocean climate and prey availability. Data on marine mammal distributions, ocean conditions, and prey availability were collected in waters overlying the continental shelf and slope from Bodega to Monterey Bays, from 1986 to 1994 and 1997 to 1999. Occurrence patterns were investigated using geographical information system (GIS), percent similarity index (PSI), multiple logistic regression, and principal component analyses. Spatial patterns of the most frequently sighted species (California sea lion Zalophus californianus, northern fur seal Callorhinus ursinus, Pacific white-sided dolphin Lagenorhyncus obliquidens, Dall's porpoise Phocoenoides dalli, harbor porpoise Phocoena phocoena,and humpback whale Megaptera novaeangliae) were related to bathymetry and changing ocean climate, and were likely to have been mediated by changes in prey availability. Temporal changes were related to migration and significant differences in ocean structure resulting from both local and large-scale processes.
\end{abstract}

KEY WORDS: California Current System · Bathymetry $\cdot$ Cetaceans $\cdot$ Coastal upwelling $\cdot$ El Niño La Niña $\cdot$ Marine mammals $\cdot$ Ocean habitats $\cdot$ Pinnipeds

\section{INTRODUCTION}

A diverse assemblage of marine mammals, including more than one-third of the world's cetacean species and 6 species of pinnipeds, occurs off central California (Bonnell et al. 1983, Dohl et al. 1983). In this area, cetacean and pinniped occurrence varies with factors such as distance from land, water temperature and depth (Huber et al. 1980, Leatherwood et al. 1980, Bonnell et al. 1983, Dohl et al. 1983, Brueggeman 1992, Allen 1994, Black 1994, Barlow 1995, Forney 2000), edges of submarine canyons (Schoenherr 1991, Croll et al. 1998, Fiedler et al. 1998), and chlorophyll concentration (Smith et al. 1986). Patterns of distribution and habitat use of cetaceans have been related to upwelling modified waters in the eastern tropical Pacific Ocean (Reilly \& Thayer 1990, Reilly \& Fiedler 1994). In the California Current System (CCS), patterns of pinniped and cetacean occurrence have also been related to the abundance of their primary prey. For example, depending on availability of presumed prey (schooling fishes or euphausiids), the humpback whale Megaptera novaeangliae is concentrated near the Farallones during some summer months (Calambokidis et al. 1991), along the shelf south of the Farallones in other months and years (Allen 1994), or more concentrated between Cordell Bank and Bodega Canyon (Calambokidis et al. 1989, 1991, Kieckhefer 1992). Herein we describe the patterns of occurrence of marine mammals in the central portion of the CCS 
using data from systematic vessel-based surveys during a 14 yr period, 1986 to 1999. The length of our data set, which included both El Niño and La Niña, allowed us to identify temporal-spatial variability in occurrence of marine mammals relative to ocean conditions over seasonal and inter-annual time scales.

The central California coast encompasses unique bathymetric features that include one of the broadest continental shelves of the west coast of the United States (50 km in some portions), narrow shelf-break and slope regions, and areas of steep bathymetric relief associated with deep submarine canyons. The water properties (e.g. temperature, salinity) in this region are spatially and temporally heterogeneous owing to hydrography driven by seasonal upwelling (Husby \& Nelson 1982, Brink 1983, Huyer 1983, Schwing et al. 1991, Smith 1992). Coastally upwelled water appears as well-defined plumes of cold filaments anchored on the coastal upwelling centers associated with capes and headlands (Traganza et al. 1981, Chelton et al. 1987) or can be centered as eddies overlying topographic features such as canyons and banks (Traganza et al. 1981, Brink 1983, Kelly 1985, Breaker \& Mooers 1986). Upwelling centers in the area occur off Point Arena, Point Reyes, Point Año Nuevo, and Point Sur (Breaker \& Mooers 1986, Schwing et al. 1991, Rosenfeld et al. 1993, Lenarz et al. 1995, Parker 1996, Baltz 1997).

The onset of upwelling (spring through late summer) differs annually, and is marked by the 'spring transition' (Huyer et al. 1990), when sea-surface temperatures drop abruptly in association with a sudden strengthening of the northwest wind (Breaker \& Mooers 1986). This equatorward wind stress, in combination with Earth's rotation, leads to the offshore transport of surface water (Ekman transport). This water is replaced by cold, nutrient-rich waters from 100 to $200 \mathrm{~m}$ in depth, changing the vertical structure of the water column (less stratification) and causing a concurrent increase in surface salinity and a drop in surface temperature (Sverdrup et al. 1942). In addition to this seasonal variability, the CCS waters also are affected by large-scale, longer-term processes associated with El Niño Southern Oscillation (Hayward 1993, Lenarz et al. 1995, Chavez 1996, Ramp et al. 1997, Schwing et al. 1997, Lynn et al. 1998). El Niño causes reduced vertical advection of nutrients and a warmer, deeper mixed layer that reduces the nutrient enrichment derived from local wind-driven Ekman transport; the opposite is true for La Niña.

Forage fishes and cephalopods of the CCS (prey of marine mammals) are subject to short-term changes in oceanographic conditions (upwelling) that result in changes in their vertical and horizontal distribution (Lenarz et al. 1991). Marine mammal prey are also sub- ject to long-term changes in oceanographic conditions (El Niño/La Niña) that have dramatic effects on their distribution and abundance (Horne \& Smith 1997, Saunders \& McFarlane 1997, Aseltine-Neilson et al. 2000). Seasonal and inter-annual ocean habitat variability, therefore, may affect marine mammal occurrence mediated by changes in prey availability.

The objectives of this study were to (1) determine seasonal and inter-annual variability in marine mammal sighting rates and species composition at the mesoscale ( $100 \mathrm{~km}$; Schwing et al. 1991), and (2) relate occurrence patterns to seasonal, and inter-annual variability in ocean conditions. To determine the relative importance of local- and regional-scale processes on mammal distribution the following hypotheses were tested: (1) The presence/absence of marine mammals along tracklines was non-random; (2) a significant association existed between mammal presence and ocean habitat variables (sea-surface temperature, thermocline depth, delta- $t$, sigma- $t$, [25.8 $\mathrm{kg} \mathrm{m}^{-3}$ isopleth], and wind speed); (3) mammal presence was significantly associated with relatively warmer sea-surface temperature (SST) and well-stratified ocean conditions and absence was associated with relatively cool SST and less-stratified ocean conditions.

\section{MATERIALS AND METHODS}

The study area, $54000 \mathrm{~km}^{2}$ off central California, extended from Bodega Bay $\left(38.32^{\circ} \mathrm{N}\right)$ to Cypress Pt. $\left(36.58^{\circ} \mathrm{N}\right)$, near Monterey, and from the coast to approximately $250 \mathrm{~km}$ offshore (Fig. 1). A total of $24361 \mathrm{~km}$ (mean $1282 \pm 506 \mathrm{~km}$ ) were surveyed along track lines.

Data collection. Mammal occurrence: Data were collected using strip transects, as described by Tasker et al. (1984) and modified by Ainley \& Boekelheide (1983; designed to survey marine mammals and seabirds) on National Marine Fisheries Service (NMFS) rockfish assessment cruises. Surveys were conducted during 1 or 2 sweeps (repeated sampling of the station grid) in early spring (April 1986-1988, FebruaryMarch 1992, and March 1993-1994), and late spring (May-June, 1986-1994, 1997-1999), the most intense portion of the upwelling season (Schwing et al. 1991, Baltz 1997). Sweeps were selected to cover similar periods across years, as cruise dates varied. Strip width was $0.3 \mathrm{~km}$ for pinnipeds and $0.8 \mathrm{~km}$ for cetaceans. At least 2 observers, stationed on the flying bridge $(12 \mathrm{~m}$ above sea level), surveyed the strip simultaneously on the side of the vessel with least glare. All mammals within the strip $(300 \mathrm{~m}$ for pinnipeds, $800 \mathrm{~m}$ for cetaceans), from directly abeam to forward, were tallied. Distance estimations were calibrated using hand- 
held range-finders (Heinemann 1981). Hand-held binoculars ( 8 to $10 \times$ ) were used to scan well forward of the ship.

Ocean habitat: The following data were collected every $15 \mathrm{~min}$ from dawn to dusk whenever the ship was underway: depth (nearest $1 \mathrm{~m}$ ); distance to nearest land mass (nearest $\mathrm{km}$ ); sea-surface salinity (SSS, nearest 1 psu), SST (nearest $0.1^{\circ} \mathrm{C}$ ), wind direction (nearest $10^{\circ}$ ), and wind speed (knots).

Conductivity-temperature-depth (CTD) data were available for 1992 to 1994 and 1997 to 1999. Data were collected from casts conducted every $16 \mathrm{~km}$ at standard hydrographic stations (Fig. 1) using methods detailed elsewhere (Sakuma et al. 1996). A MATLAB program (Adams 1998: J. Adams, Moss Landing Marine Laboratories, pers. comm.) was used to extract the following variables from each CTD cast: (1) thermocline depth, defined as the inflection point in the temperature depth profile where the greatest temperature change occurred over a $20 \mathrm{~m}$ interval (surface to $180 \mathrm{~m}$ depth; (2) delta- $t$, the vertical component of the temperature gradient, calculated as the temperature difference (nearest $0.1^{\circ} \mathrm{C}$ ) between

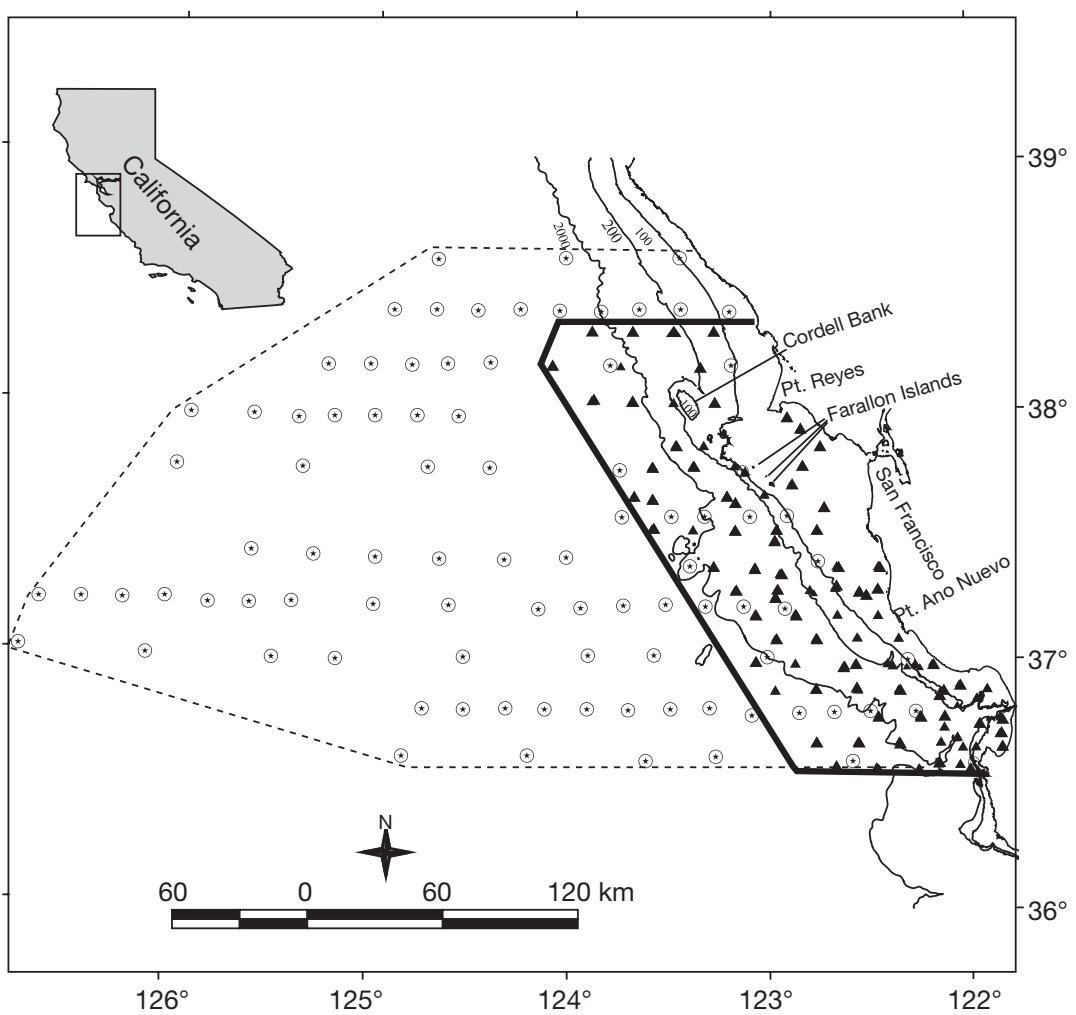

Fig. 1. Study area (early spring survey perimeter depicted by dashed line and late spring survey perimeter depicted by solid line) off central California, indicating location of CTD stations during early spring surveys $\left(^{(}\right)$and late spring surveys ( $(\mathbf{\Lambda})$ and depth (m) the top of the thermocline and a point $20 \mathrm{~m}$ below it; (3) sigma- $t$ or depth of the $25.8 \mathrm{~kg} \mathrm{~m}^{-3}$ isopycnal (potential density anomaly surface; Baltz 1997). For each cast, the MATLAB program successively differentiated each temperature value from the surface to a maximum depth of $200 \mathrm{~m}$, identified all inflection points, and then selected the inflection point depth having the largest delta- $t$ over $20 \mathrm{~m}$. Thermocline depth and delta- $t$ were selected as variables because of their known association with stratification and biological productivity (Baltz 1997, Gargett 1997). The $25.8 \mathrm{~kg} \mathrm{~m}^{-3}$ isopycnal was selected as a variable because of its association with upwelled water and the dominant thermocline, and because the spatial distribution of this density is also a proxy for stratification (Baltz 1997).

We used daily and monthly upwelling indices data publicly available from Pacific Fisheries Environmental Laboratory (www.pfeg.noaa.gov/products/PFEL) for $36^{\circ} \mathrm{N}, 122^{\circ} \mathrm{W}$ (south of the study area) and $39^{\circ} \mathrm{N}$, $125^{\circ} \mathrm{W}$ (north of the study area), to identify the phasing and intensity of upwelling during survey periods. The upwelling index measures offshore Ekman transport, and thus upward vertical water motion near the coast, the main features of coastal upwelling. A comparison of upwelling indices before and during survey periods was used to provide insight into factors associated with changes in water-column structure.

Prey availability: Fishes and squid were identified from mid-water trawls conducted at night during the survey periods (1992 to 1994, 1997 to 1999), by courtesy of the Tiburon Laboratories, National Marine Fisheries Service (NMFS). Trawls were conducted by NMFS at 5 to 6 stations along each of 7 transects (described in detail by Sakuma et al. 1996). Although temporal differences were too great for a direct comparison between mid-water trawl data and marine mammal surveys (over the same transects, marine mammal surveys were performed during daylight, whereas mid-water trawls were conducted during darkness), these data were used as a proxy for biological conditions and potential prey availability. Catch per unit effort (CPUE; number of fish/number of hauls), effort (number of hauls), and frequency of occurrence (FO; presence of each species haul ${ }^{-1}$ ) were calculated.

Data analysis. Data were analyzed on several spatial and temporal scales using multivariate analysis and GIS (Geographical Information System). Spatial and temporal survey effort was unequal among years; therefore, trackline maps were created and visually 
inspected to select years with similar spatial and temporal survey effort. We selected 6 yr (1992 to 1994, and 1997 to 1999) for final analysis.

Sample units: The analysis units were consecutive 15 min segments (at 10 knots $=\sim 4 \mathrm{~km}$ ) along the transect lines. Because the ship's speed varied, 15 min sample units were not of equal length. Lengths of sample units per survey period were calculated (range 0.6 to $10.3 \mathrm{~km}$ ). On the basis of a preliminary multiple logistic regression, we determined that the presence/ absence of marine mammals was significantly associated with length of the sample units. Therefore, only sample units $\pm 2 \mathrm{SD}$ (2.6 to $6.0 \mathrm{~km}$ ) in length were used in the analyses.

Autocorrelation: Spatial autocorrelation refers to adjacent sampling units that are more strongly related to each other than to more distant units. This is of concern in hypothesis testing, because samples that are closer together are more similar than samples that are farther apart (e.g. marine mammal sightings, depending on species, tend to be clustered spatially). Therefore, correction for potential redundancy of information must be addressed (Griffith 1987). Because successive sample units may not be independent, an analysis of adjacent sample units was performed as follows: the proportion of pairs of sample units containing no animals present (AA), animals present in one of the pairs (PA), and animals present in both pairs (PP) were calculated for (spatial lags) distances of 1 to 5 sample units apart. Thus for each comparison (AA) + (PA) + $(\mathrm{PP})=$ coefficient of dispersion. Paired sample units at these distances were tested for significance with SPSS (Statistical Package for the Social Sciences; SPSS 1992) RxC Crosstabs, Pearson chi-square, and likelihood ratio tests and were set at alpha levels $=0.20$ to avoid Type II errors (Tabachnick \& Fidell 1996). Because we tested $\mathrm{n}$ (species) $\times 5$ (lags), we would expect $(0.20 \times$ $\mathrm{n} \times 5$ ) comparisons to yield a significant autocorrelation at the significance level of alpha $=0.20$ merely by chance. Our results indicated no significant differences for any combination of pairs ( $p<0.05)$; therefore, adjacent units were considered independent for subsequent analyses.

Ocean habitat: Ocean habitat was defined by SST, wind speed, thermocline depth, delta- $t$, sigma- $t$, and bathymetry. Nonparametric statistics were used to test for habitat differences because of skewed distributions. SST differences among early and late survey periods and among all late survey periods were tested for significance using Kruskal-Wallis 1-way tests. SST differences within an upwelling season were tested for significance using the Kolmogorov-Smirnov $z$ test.

ArcView 3.2 Geographical Information System (GIS) software and its Spatial Analyst Extension were used to investigate spatial differences in SST among surveys. All GIS map projections were UTM 1983 Zone 10. SST grids and isotherms were created at a scale of $4 \mathrm{~km}$ (sample unit scale) and the inverse distance weighted interpolation method was used to create SST maps. Upwelling polygons that contained upwelling plumes emanating from upwelling centers near Pt. Reyes and Pt. Año Nuevo were mapped, and area and perimeter were calculated. Upwelling plumes (defined as a relatively cool pool of water -1 SD from the mean SST) were derived from shipboard data. Advanced very high resolution radiometry (AVHRR) images were acquired from the West Coast Regional Node NOAA Southwest Fisheries Science Center (SWFSC) Pacific Fisheries Environmental Laboratory (http://coastwatch.pfel.noaa.gov). Because archived data only were available for 1993 and 1994, composites for the 1993 survey period (23 NOAA-11 satellite passes) and the 1994 survey period (16 NOAA-11 satellite passes) were used. Satellite images for the 1997 to 1999 survey periods were available and daily S7 (night time nonlinear split-window algorithm) and D7 (daytime nonlinear split-window algorithm) images were used to verify SST derived from shipboard data. Because they are corrected for atmospheric bias, the S7 and D7 have more accurate absolute temperatures (http://coastwatch.pfel.noaa.gov). Visual assessments were performed and a comparison of AVHRR images (overlaid with marine mammal sighting locations) corresponded well with maps of sea-surface isotherms derived from shipboard data (overlaid with marine mammal sighting locations).

Extracted CTD variables were tested for significant differences using a Kruskal-Wallis test and imported into ArcView. The spatial analyst extension was used to map the CTD station locations, thermocline depth, delta- $t$ (thermocline strength) and the 25.8 isopleth during 1992 to 1994 and 1997 to 1999 . Vertical oceanographic variables at a scale of $16 \mathrm{~km}$ were interpolated with the inverse distance-weighted method to $4 \mathrm{~km}$ (sample unit scale) with ArcView. ArcView spatial analyst reclassify function was used to generate mean $( \pm)$ gridded cell counts for CTD variables: thermocline depth, delta- $t$, and sigma- $t$.

We mapped bathymetry data acquired from the US Geological Survey (USGS) (datum: nad27; Projection: geographic; map scale: 1:250 000; arc increments 10 to 200 at $10 \mathrm{~m}$ intervals, 200 to 4000 at $50 \mathrm{~m}$ intervals). Contours were optically scanned from the NOAA 1:250 000 charts for the area; the average mean distance between points was $250 \mathrm{~m}$ with an average standard deviation of $184 \mathrm{~m}$. Data files in dBase IV (Borland International) format were imported into ArcView, and location of marine mammal sightings and sea surface isotherms derived from shipboard 
measurements were mapped and layered with the bathymetry data.

Marine mammal distribution: Sighting rates of marine mammals (sightings $100 \mathrm{~km}^{-1}$ ) were calculated for all survey periods and tested for normality and homoscedacity. The grand mean of SST $\left(12.26^{\circ} \mathrm{C}\right.$; $\mathrm{n}=19)$ was used to define warm $\left(>12.26^{\circ} \mathrm{C}\right)$ and cool $\left(<12.26^{\circ} \mathrm{C}\right)$ survey periods. Because variances were not equal, a Mann-Whitney $U$-test (Zar 1984) was used to assess differences in sighting rates between between warm and cool water periods, and early and late spring surveys. A 2 -sample $t$-test was used to assess significant differences between pinniped and cetacean sighting rates. The proportion of all mammals sighted was compared for each late-spring survey period among years, and survey periods within years, using a percentage similarity index (PSI, Silver 1975: PSI $=\Sigma$ minimum [FiSi] where the sum of the minimum proportion of sightings of any given species is the first [Fi] or second [Si] sample, across all species). The value of the index ranges from 0.0 to 1.0 with values increasing as the similarity in species composition and in relative number of sightings of species increases between 2 survey periods. A significance level was set at 0.67 ( $\geq 85$ th percentile) for a significantly similar index and 0.36 ( $\leq 10$ th percentile) for a significantly different index.

Species sighted most frequently were selected for the PSI analyses. These were the California sea lion Zalophus californianus, the northern fur seal Callorhinus ursinus the Pacific white-sided dolphin Lagenorhyncus obliquidens, the Dall's porpoise Phocoenoides dalli, the harbor porpoise Phocoena phocoena, and the humpback whale Megaptera novaeangliae. Species sighted infrequently were grouped into different categories referred to as 'other'; the gray whale Eschrichtius robustus, the minke whale Balaenoptera acutorostrata, the sei whale Balaenoptera borealis, and unidentified balaenopterids were grouped as 'mysticete sp.'; the common dolphin Delphinus, the Risso's dolphin Grampus griseus, northern right whale dolphin Lissodelphis borealis, the killer whale Orcinus orca, Cuvier's beaked whale Ziphius cavirostris, and unidentified odontocetes were grouped as 'odontocete sp.'; and the Steller sea lion Eumetopias jubatus, the northern elephant seal Mirounga angustirostris, the harbor seal Phoca vitulina, and unidentified seals/sea lions were 'pinniped sp.'.

The presence and absence of marine mammals per sample unit was tested for a non-random distribution using the binomial frequency distribution. Differences between observed and expected frequencies were tested for significant differences with a Pearson chi square likelihood ratio test. A coefficient of dispersion (CD) was calculated to quantitatively indicate the dispersion by comparing the variance to mean ratio, with a 95\% confidence zone of random dispersal (Fowler et al. 1998). If the observed CD was greater than the expected value, the distribution was clumped; if observed CD was less than the expected value, the distribution was most probably uniform; and if the observed and expected $C D \approx 1$, the distribution followed a Poisson process.

Some researchers have shown that wind speed is an important factor affecting sighting conditions (Barlow 1988, Barlow \& Forney 1994), and thus the ability to detect small inconspicuous marine mammals e.g. the harbor porpoise. We investigated the effects of wind speed on sighting rates with a Pearson correlation analysis and the results indicated no significant correlation between wind speed and sighting rates $(\mathrm{r}<$ $0.027 ; \mathrm{p}=0.912 ; \mathrm{n}=19$ ). The mean wind speed during the surveys of this study was within moderate sea conditions (Beaufort 5 to $6 ;<25$ knots) and in this study of marine mammal distribution, we feel the potential biases associated with effects of wind are negligible (Table 1).

Marine mammals and ocean habitat: Locations of marine mammal sightings were mapped over sea-surface isotherms and were visually evaluated to assess trends among survey periods. Interpolated GIS maps of thermocline depth, delta- $t$, and sigma- $t$ depth were overlaid with sighting locations and were spatially linked to mammal sighting location and surface environmental data for further statistical analysis. To determine which oceanographic variables were related to the presence/absence of marine mammals, a backward, stepwise, multiple logistic regression based on the likelihood-ratio statistic was performed using SPSS Version 10.0. The binary dependent variable was the presence and absence of the numerically dominant marine mammals (see last subsection) and the continuous independent variables were water depth, SST, thermocline depth, delta- $t$, sigma- $t$ depth and wind speed. Because logistic regression is sensitive to extremely high correlations among predictor variables (Tabachnik \& Fidell 1996), the continuous predictor variables were screened for multicollinearity using a Pearson correlation, and correlated ( $\mathrm{r}>0.60)$ variables (thermocline depth) were not included in the analysis. Because the presence of an animal occurred in only $25 \%$ of the sample units analyzed (units with animal present/ total number sample units, or 736/2906), models performed well on the absence of animals. To more clearly explain the patterns revealed in logistic regression results, a principal component analysis (PCA) was used to investigate details among ocean habitat variables associated with the presence of marine mammals (depth of water and sigma- $t$, delta- $t$, SST and wind speed), and to assess the total variance and 
importance of each ocean habitat variable associated with marine mammal presence. PCA combined the ocean habitat variables into a set of factors and quantified the total variance of ocean habitat variables associated with the presence of marine mammals. The factors (or components) are defined by the high-loading variables (component loadings). The greater the component loading, the more important the variable is in explaining the observed variance. Only component loadings $\geq 0.300$ were interpreted as ecologically significant (Tabachnick \& Fidell 1996). To reveal patterns of discrete assemblages, differences in PCA factor scores among species were tested for significance with a Kruskal-Wallis test (due to unequal variances), and Games and Howell multiple comparison tests (Day \& Quinn 1989) were used to identify significant differences among paired comparisons. All means are given with \pm 1 SD.

\section{RESULTS}

\section{Ocean habitat}

SSTs were significantly different $(p<0.001)$, between early (February/March/April) and late (May/
June) spring surveys during 1986 to 1988 and 1992 to 1994 ; and inter-annual SSTs were significantly different $(p<0.001)$ between late-spring surveys of 1986 to 1994 and 1997 to 1999 (Kruskal-Wallis 1-way ANOVA). Mean SSTs during early-spring surveys ranged from $10.8 \pm 0.9^{\circ} \mathrm{C}(1987)$ to $13.8 \pm 0.5^{\circ} \mathrm{C}(1992)$, whereas mean SSTs during late-spring survey periods ranged from $9.6 \pm 0.9^{\circ} \mathrm{C}(1999)$ to $14.0 \pm 1.2^{\circ} \mathrm{C}(1997)$. Early spring SSTs were cooler than those in late spring in 1986 and 1987, similar in 1988, 1992 and 1993, and warmer in 1994. SSTs in late spring of 1986, 1987, 1992, 1993, 1997 and 1998 were significantly warmer than in 1988, 1989, 1994, and 1999. During 1999, Sweep 3 was significantly warmer than Sweep 1 ( $p<$ 0.001).

Comparisons between SSTs, wind speed, and daily mean upwelling indices indicated that cooler SSTs coincided with higher wind speeds and high upwelling-index values, and warmer SSTs coincided with lower wind speeds and low upwelling index values (Table 1). For example, the relatively low wind speeds of early spring 1992 to 1993 coincided with negative upwelling indices (downwelling) and relatively warm SSTs. During late spring, the relatively high values of the upwelling index coincided with higher wind speeds and cooler SSTs (1994 and 1999),

Table 1. Summary of ocean structure and environmental conditions during early and late spring surveys ( ${ }^{*}$ : El Niño years). Percent area for thermocline depth (DEP), sigma- $t$ (SIGMAT), and delta- $t$ (DELTAT) were derived from GIS (Geographical Information System) measurements using ArcView spatial analyst reclassify function. na: no upwelling plumes present; nan: data not in CTD casts; upwelling index values are survey daily means. SST: sea surface temperature. CPUE: catch per unit area. Means are \pm 1 SD. 1999_1 \& 1999_3: Sweeps 1 \& 3 of 1999: Mean upwelling index measured at $39^{\circ} \mathrm{N}, 125^{\circ} \mathrm{W}\left(\mathrm{m}^{3} \mathrm{~s}^{-1}\right.$ per $100 \mathrm{~m}$ coastline)

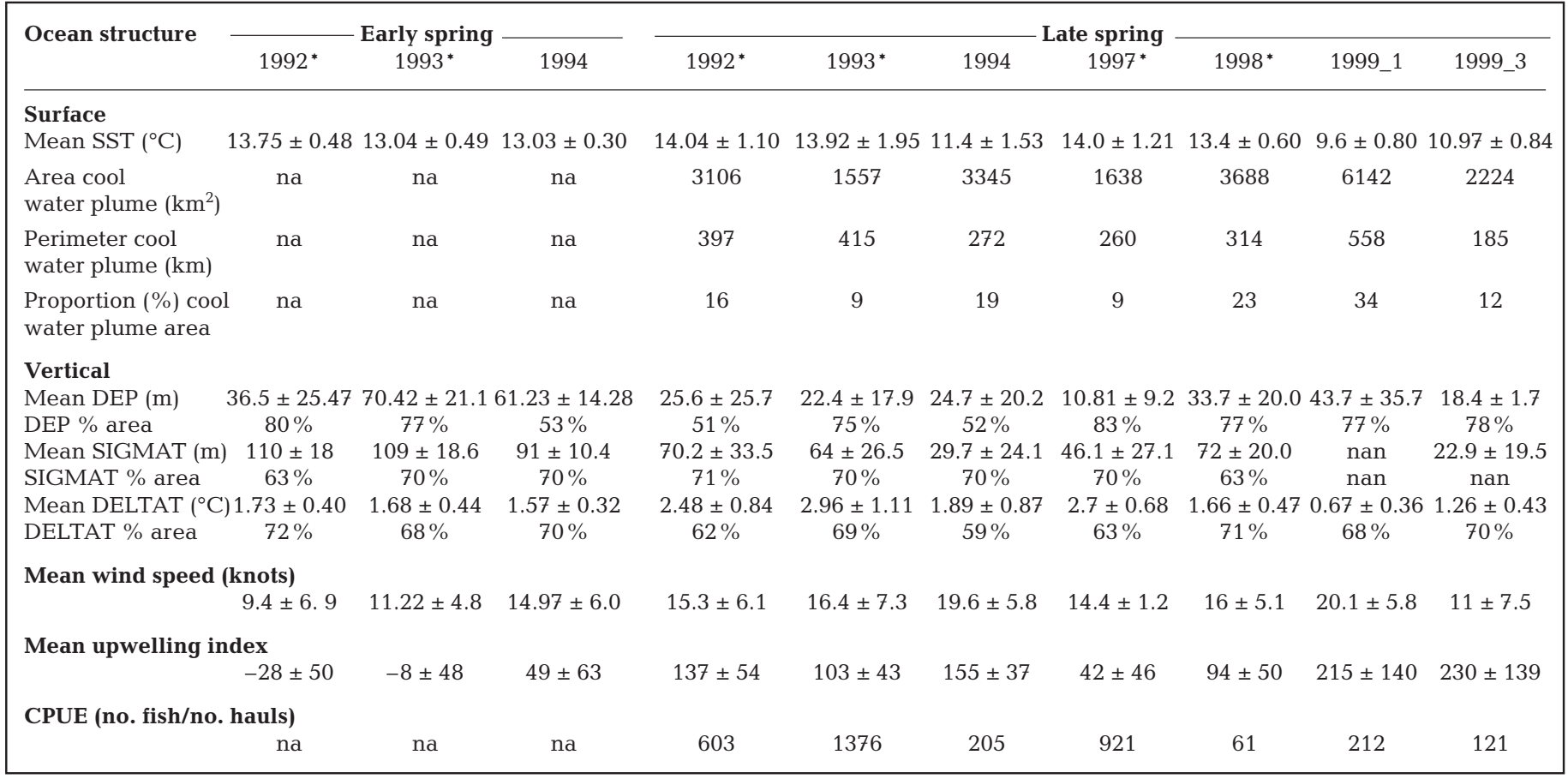


whereas relatively lower values of the upwelling index coincided with relatively warmer SSTs and lower wind speeds (1997 and 1998). The greatest difference in mean wind speed during the late-spring survey periods occurred between 1986 and Sweep 1 of 1999. The mean wind speed was more than twice as strong in 1999 (Sweep 1) than in1986.

During the 1992 to 1994,1997 to 1999 surveys, sigma- $t$, thermocline depth and strength (delta- $t$ ) were significantly different among years and seasons (Kruskal-Wallis 1 -way ANOVA; $\mathrm{p}<0.001$ ). For all comparisons, the marked changes in vertical ocean structure in early and late spring coincided with marked changes in the upwelling index (Table 1). A deeper thermocline and a less stratified water column occurred during the early-spring surveys (upwelling index low or negative) compared with the late-spring surveys (upwelling index greater). The greatest difference in mean depth of the dominant thermocline between early and late spring occurred in 1993. During early spring in 1993, mean thermocline depth was twice as deep as in late spring; mean sigma- $t$ depth in early spring was almost twice as deep as in late spring, and thermocline strength (delta- $t$ ) in late spring increased almost 2-fold compared with early spring. During late-spring surveys, ocean conditions reflected oscillations between upwelling and relaxation: ocean structure varied between relatively well-mixed (deep thermocline and weak delta- $t$ ) and stratified (sharp shallow thermocline and relatively shallow sigma- $t$ ). Depths of thermocline in 1998 (coincident with relatively low upwelling-index values) and Sweep 1 of 1999 (coincident with relatively high-upwelling index values) were deeper than in all other surveys (Table 1). The greatest difference in the mean depth of the dominant thermocline between late-spring surveys occurred in 1997 and 1998. During late spring of 1998, the mean thermocline depth was 3 times deeper than in late spring 1997; $67 \%$ of the 1998 survey area contained thermocline depths of 9 to $48 \mathrm{~m}$, whereas $83 \%$ of the 1997 survey area contained thermocline depths of 3.9 to $18 \mathrm{~m}$. In late spring of 1998 , mean sigma- $t$ depth was $20 \mathrm{~m}$ deeper, and delta- $t$ was lower than during late spring of 1997.

During Sweeps 1 and 3 of 1999, the depth of the thermocline and delta- $t$ varied significantly (KolmogorovSmirnov z test; $\mathrm{p}<0.001$ ). During 1999 (Sweep 1), mean thermocline depth was 2 times deeper than during Sweep 3: $76 \%$ of the survey area contained thermocline depths of 25.6 to $68.9 \mathrm{~m}$ during Sweep 1, whereas $78 \%$ of the survey area contained thermocline depths of 6.3 to $30 \mathrm{~m}$ during Sweep 3. During Sweep 1, thermocline strength (mean delta- $t$ ) was approximately half the strength of the thermocline of Sweep 3; $68 \%$ of the survey area during Sweep 1 con- tained delta- $t$ values of 0.3 to $0.8^{\circ} \mathrm{C}$, whereas $70 \%$ of the survey area during Sweep 3 contained delta- $t$ values of 1.0 to $1.6^{\circ} \mathrm{C}$. Because the $25.8 \mathrm{~kg} \mathrm{~m}^{-3}$ isopycnal was only present during Sweep 3, no comparisons were conducted with this variable.

\section{Marine mammal distribution}

We observed 23 species (5 of which could only be identified to genus, Table 2); $54 \%$ of all sightings were pinnipeds, $36 \%$ odontocetes, $9 \%$ mysticetes and $1 \%$ mustelids. The most frequently sighted species were the California sea lion, the northern fur seal, the Pacific white-sided dolphin, Dall's porpoise, the harbor porpoise and the humpback whale.

Sightings were not equally distributed among sample units along track lines during 1992 to 1994, 1997 to 1998, and 1999. Observed and expected binomial frequency distributions of the presence/absence of marine mammals per sample were significantly different for all survey periods ( $p<0.025)$. Except for 1997 (when the CD was less than that expected, indicating a uniform distribution), marine mammals displayed a clumped distribution.

Marine mammals were widely distributed on the continental shelf $(<200 \mathrm{~m})$, along the shelf-break and slope ( 200 to $2000 \mathrm{~m}$ ) and seaward of the $2000 \mathrm{~m}$ isobath during early and late spring surveys (Figs. 2 \& 3). Generally, harbor porpoise were sighted near-shore, in shallow waters (mean depth $60 \pm 56$ m, Figs. 2d \& 3d); Pacific white-sided dolphins were sighted along the shelf-break (depth $1042 \pm 864$ m; Figs. 2a \& 3a); northern fur seals were observed in deep water (2789 \pm 1299 m, Figs. 2b \& 3b); California sea lions (303 \pm 620 m, Figs. 2e \& 3e), humpback whales (608 \pm 807 m, Figs. 2f \& 3f); and Dall's porpoise (877 $\pm 1335 \mathrm{~m}$, Figs. 2c $\& 3 c)$ were observed throughout the survey area.

Sighting rates did not differ significantly (MannWhitney $U$-test, $\mathrm{p}>0.05$ ) between early and late spring surveys regardless of year (Fig. 4). No significant differences existed between mean pinniped and mean cetacean sighting rates during early spring ( $t=$ to 0.84 , $\mathrm{df}=10, \mathrm{p}>0.05)$ and late-spring $(t=0.01, \mathrm{df}=22, \mathrm{p}>$ $0.05)$ survey periods. Nevertheless, the frequently sighted species were seen during most early and late spring surveys, but percentages of each species varied (Figs. 5 \& 6). In early spring, species composition was significantly similar (PSI > 67.0) during 1987 and 1988, 1986 to 1994 , and 1992 to 1993 , with northern fur seals more frequent during 1992 and 1993 (Fig. 5). The composition of pinniped species during early and late spring changed markedly in 1992 and 1993. Northern fur seals were seen more frequently in early spring, whereas California sea lions were seen more fre- 
Table 2. Species, number of sightings, and number of marine mammals observed during surveys off central California 1986 to 1994 and 1997 to 1999. Codes: abbreviations used for species in Figs. 2 \& 3

\begin{tabular}{|c|c|c|c|c|}
\hline Species & Common name & Codes & $\begin{array}{l}\mathrm{Nu} \\
\text { sightings }\end{array}$ & $\begin{array}{l}\text { of } \\
\text { animals }\end{array}$ \\
\hline \multicolumn{5}{|l|}{ Mysticetes } \\
\hline Eschrichtius robustus & Gray whale & WHGR & 10 & 38 \\
\hline Megaptera novaeangliae & Humpback whale & WHUM & 109 & 242 \\
\hline Balaenoptera acutorostrata & Minke whale & WMIN & 14 & 18 \\
\hline Balaenoptera borealis & Sei whale & WSEI & 2 & 2 \\
\hline Balaenoptera spp. & Unidentified balenopterid & WHAL & 9 & 11 \\
\hline \multicolumn{5}{|l|}{ Odontocetes } \\
\hline Dolphin spp. & Unidentified dolphin & DOLP & 14 & 29 \\
\hline Delphinus capensis & Common dolphin & DOCO & 5 & 1407 \\
\hline Lagenorhynchus obliquidens & Pacific white-sided dolphin & DOPW & 145 & 1603 \\
\hline Grampus griseus & Risso's dolphin & DORI & 26 & 207 \\
\hline Lissodelphis borealis & Northern right whale dolphin & DORW & 16 & 259 \\
\hline Phocoena phocoena & Harbor porpoise & POHA & 134 & 327 \\
\hline Phocoenoides dalli & Dall's porpoise & PODA & 239 & 1011 \\
\hline Porp spp. & Unidentified porpoise & PORP & 2 & 3 \\
\hline Orcinus orca & Killer whale & WKIL & 5 & 12 \\
\hline Beaked whale spp. & Unidentified beaked whale & WHBK & 5 & 19 \\
\hline Ziphius cavirostris & Cuvier's beaked whale & WBCU & 2 & 8 \\
\hline \multicolumn{5}{|l|}{ Pinnipedia } \\
\hline Zalophus californianus & California sea lion & SLCA & 344 & 862 \\
\hline Eumetopias jubatus & Northern sea lion & SLNO & 14 & 28 \\
\hline Callorhinus ursinus & Northern fur seal & FSNO & 356 & 518 \\
\hline Mirounga angustirostris & Northern elephant seal & SENE & 109 & 111 \\
\hline Phoca vitulina & Harbor seal & SEHA & 51 & 51 \\
\hline Pinniped spp. & Unidentified pinniped & PINN & 4 & 4 \\
\hline \multicolumn{5}{|l|}{ Fissipedia } \\
\hline Enhydra lutris & Sea otter & OTTS & 13 & 15 \\
\hline Total all species & & & 1628 & 6785 \\
\hline
\end{tabular}

quently in late spring. Species composition was dissimilar between early and late spring surveys for other years $(\mathrm{PSI}=56.0$ in 1986, 45.0 in $1987,41.0$ in 1988 , 37.0 in 1992, and 64.0 in 1994).

Species composition during late spring was similar for 1992 and 1993, and for 1992 and 1998 (El Niño), with California sea lions seen more frequently (PSI > 67.0; Fig. 6). Species composition also was similar in 1991, 1997 and 1999 Sweep 3 (PSI > 67.0; Fig. 6) with northern fur seals, Dall's porpoise and humpback whales seen more frequently. Species composition during the 1999 Sweep 1 was markedly different from that in 1988, 1990 and 1992, with the Pacific whitesided dolphin seen more frequently in 1999 and Dall's porpoise seen more frequently in 1988 and 1990.

\section{Marine mammals and ocean habitat}

Sighting rates were positively correlated with mean SSTs (Pearson correlation coefficient $=0.57, \mathrm{p}<0.01$ ), but there were no significant differences $(\mathrm{p}>0.05)$ between sighting rates during warm water $\left(>12.26^{\circ} \mathrm{C}\right)$ and cool water $\left(<12.3^{\circ} \mathrm{C}\right)$ surveys. During late spring surveys, the lowest sighting rate (3.1 sightings $100 \mathrm{~km}^{-1}$ ) occurred during 1988, a relatively cool-water period $\left(11.0 \pm 0.9^{\circ} \mathrm{C}\right)$, whereas the highest sighting rate $(18.3$ sightings $100 \mathrm{~km}^{-1}$ ) occurred during 1997, a relatively warm-water period $\left(14.0 \pm 1.2^{\circ} \mathrm{C}\right)$. This pattern, however, was not observed during early spring surveys when the highest sighting rate (8.2 sightings $100 \mathrm{~km}^{-1}$ ) occurred during 1992, a relatively warm water period $\left(13.7 \pm 0.5^{\circ} \mathrm{C}\right)$. The lowest sighting rate $(2.1$ sightings $100 \mathrm{~km}^{-1}$ ) also occurred during a relatively warmwater period $\left(1994 ; 13.0 \pm 0.3^{\circ} \mathrm{C}\right)$.

When all species were combined for the 1992 to 1998 survey periods, stepwise logistic regression indicated that 3 variables were important for predicting the presence/absence of marine mammals: depth of water, sigma- $t$ and wind speed (Table 3 ). For all species combined, the sigma- $t$ model indicated that as the depth of sigma- $t$ increased, the likelihood that animals were present decreased, and as wind speed increased, the likelihood that animals were present or seen decreased. Depending on species, most marine mammals were generally found where sigma- $t$ depths were relatively shallow and wind speeds were moderate to low. Some species were also found where sigma- $t$ was deeper and when wind speeds were greater. There are 3 considerations to be made in interpreting the results 

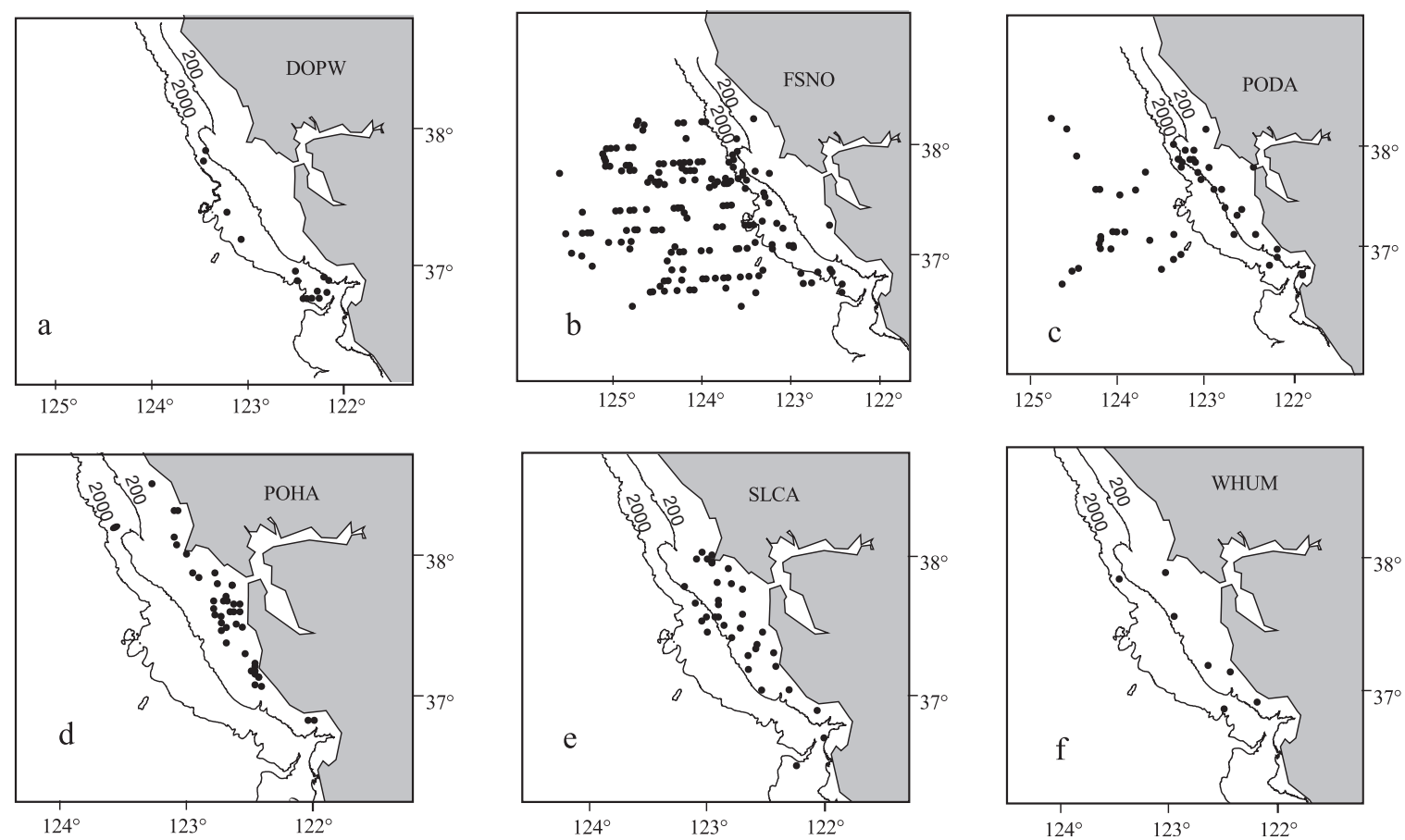

Fig. 2. Sighting locations of (a) Pacific white-sided dolphin Lagenorhynchus obliquidens (DOPW), (b) northern fur seal Callorhinus ursinus (FSNO), (c) Dall's porpoise Grampus griseus (PODA), (d) harbor porpoise Phocoena phocoena (POHA), (e) California sea lion Zalophus californianus (SLCA) and (f) humpback whale Megaptera novaeangliae (WHUM) during early spring surveys of 1986 to 1988 , and 1992 to 1994
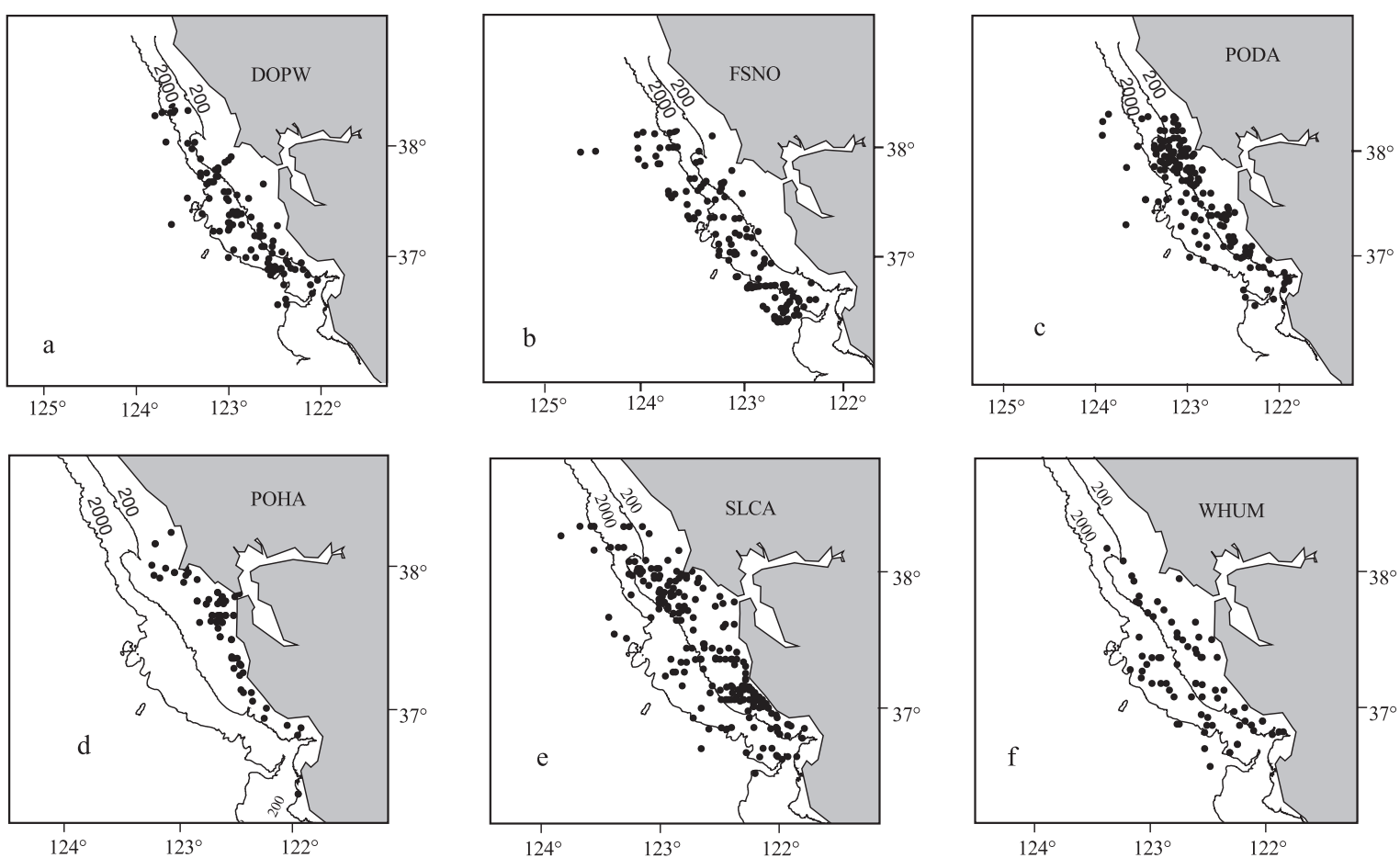

Fig. 3. Sighting locations of (a) Pacific white-sided dolphin Lagenorhynchus obliquidens (DOPW), (b) northern fur seal Callorhinus ursinus (FSNO), (c) Dall's porpoise Grampus griseus (PODA), (d) harbor porpoise Phocoena phocoena (POHA), (e) California sea lion Zalophus californianus (SLCA) and (f) humpback whale Megaptera novaeangliae (WHUM) during late spring surveys of 1986 to 1994 , and 1997 to 1999 


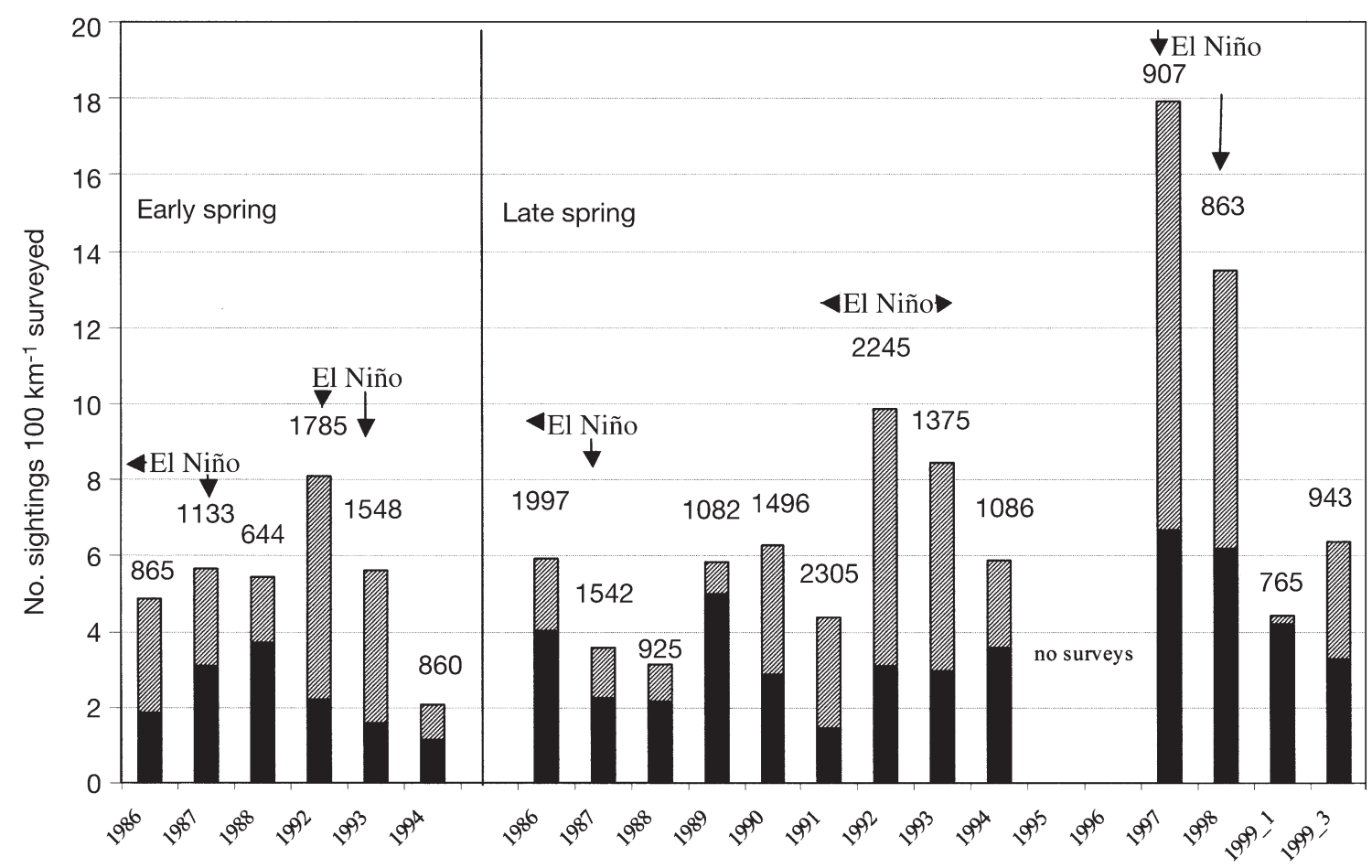

Fig. 4. Sighting rates of marine mammals during early-spring survey periods 1986-1988, 1992-1994, and late-spring surveys of 1986-1994, 1997-1999. Solid black bars: number of cetacean sightings; hatched bars: number of pinniped sightings; numbers above bars: km surveyed. 1999_1 \& 1999_3: Sweeps 1 \& 3 of 1999. Arrows indicate start and end of El Niño

Northern fur seal $\square$ Dall's porpoise Pacific white-sided dolphin

a

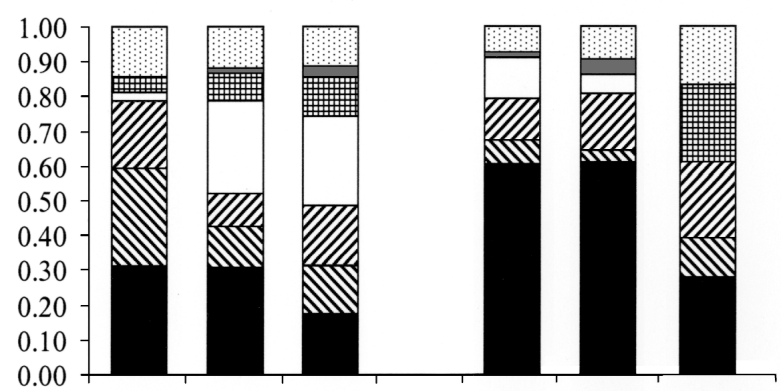

b 1.00

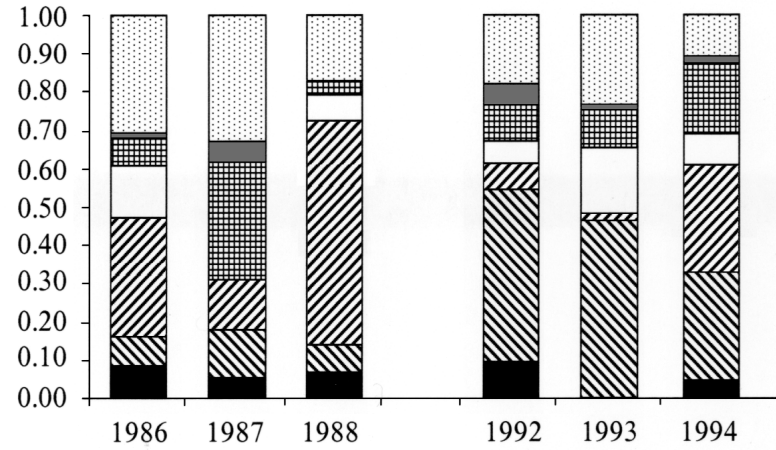

of the stepwise logistic regression analyses. First, there was a significant correlation $(>0.60)$ between the depth of sigma- $t$ and thermocline depth, and between delta- $t$ and thermocline depth (>0.60). Therefore (because our interest was in delta- $t$, the strength of the thermocline), sigma- $t$ and delta- $t$ were included in the final model (and thermocline depth was excluded). Second, marine mammals were observed in only $25 \%$ of the 2906 sample units. Therefore, multiple logistic regression models tended to predict conditions associated with absence rather than presence. Third, the model produced by logistic regression is nonlinear (Tabachnick \& Fidell 1996), the outcomes are predicted not from a single variable, but from the set of variables, and the p-values are indicators of relative importance among variables.

For each species, stepwise results indicated that ocean depth was a significant predictor of the presence for all taxa except the Pacific white-sided dolphin,

Fig. 5. Relative proportion of sightings of marine mammals during (a) early and (b) late spring surveys. See 'Materials and methods' and Table 6 for species grouped as 'other': DOCO, DORI, DORW, PORR, WKIL, WHBK, WBCU, WHGR, WMIN, WSEI, WHAL, SLNO, SENE, SEHA, PINN. See Table 2 for explanation of species codes 


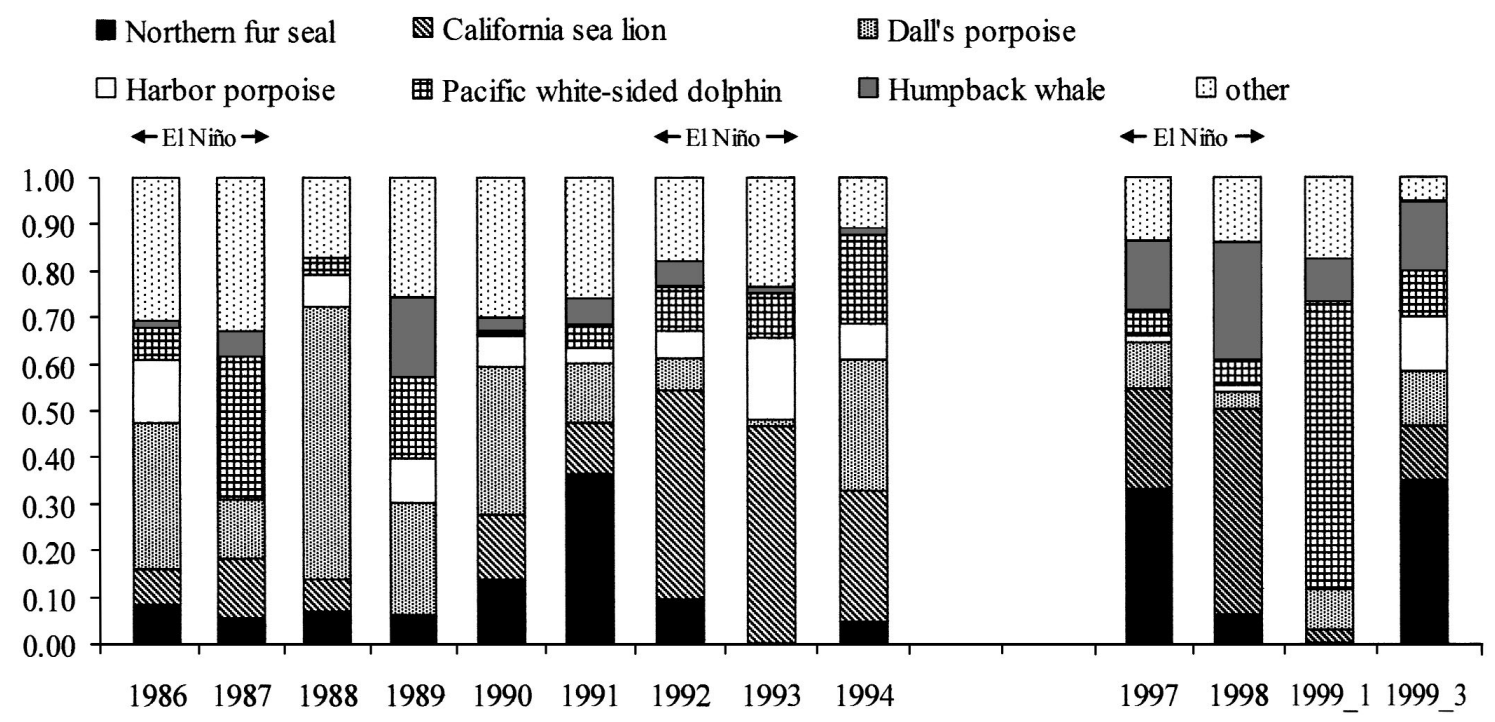

Fig. 6. Relative proportion of sightings of marine mammals during late-spring surveys of 1986-1994 and 1997-1999. See 'Materials and methods', and Table 6 for species grouped as 'other'. 1999_1 \& 1999_3: Sweeps 1 \& 3 of 1999

Table 3. Regression coefficients for $25.8 \mathrm{~kg} \mathrm{~m}^{-3}$ (sigma- $t$ ) model using backward, stepwise, multiple logistic regression of habitat variables: depth of water (DPT), sea surface temperature (SST), wind speed (WSP), sigma- $t$ (SIGMAT) and delta- $t$ (DELTAT). Significance was tested for presence/absence of all marine mammals combined, and with dominant species only, during 1992-1994, and 1997-1998 survey periods. Significance levels of ${ }^{*} p<0.05,{ }^{* *} p<0.01$, and ${ }^{* * *} p<0.001$ are shown. Blank indicates coefficient was not significant

\begin{tabular}{|c|c|c|c|c|c|c|c|}
\hline $\begin{array}{l}\text { Sigma-t } \\
\text { model }\end{array}$ & $\begin{array}{c}\text { All } \\
\text { mammals }\end{array}$ & $\begin{array}{l}\text { Pacific white- } \\
\text { sided dolphin }\end{array}$ & $\begin{array}{c}\text { Northern } \\
\text { fur seal }\end{array}$ & $\begin{array}{l}\text { Dall's } \\
\text { porpoise }\end{array}$ & $\begin{array}{l}\text { Harbor } \\
\text { porpoise }\end{array}$ & $\begin{array}{l}\text { California } \\
\text { sea lion }\end{array}$ & $\begin{array}{c}\text { Humpback } \\
\text { whale }\end{array}$ \\
\hline DPT & $<0.000^{*}$ & & $0.001^{* * *}$ & $<0.000^{*}$ & $-0.008^{* * *}$ & $-0.001^{* * *}$ & $-0.001^{* * *}$ \\
\hline SST & & & & $-0.409^{* *}$ & $\begin{array}{r}0.655^{* * *} \\
-0.066^{* * *}\end{array}$ & & \\
\hline $\begin{array}{l}\text { WSP } \\
\text { SIGMAT }\end{array}$ & $\begin{array}{l}-0.055^{* * *} \\
-0.010^{* * *}\end{array}$ & $-0.051^{*}$ & $-0.074^{* * *}$ & $-0.080^{* * *}$ & $\begin{array}{l}-0.096^{* * *} \\
-0.017^{* * *}\end{array}$ & $-0.012^{* * *}$ & $-0.051^{*}$ \\
\hline $\begin{array}{l}\text { SIGMAT } \\
\text { DELTAT }\end{array}$ & $-0.010^{* * *}$ & & & & $\begin{array}{l}-0.017^{* * *} \\
-1.455^{* * *}\end{array}$ & & $-0.013^{*}$ \\
\hline
\end{tabular}

indicating that these dolphins were found over the shelf-break where depth varied greatly. Northern fur seals were found off the continental shelf in deeper water; harbor porpoise, California sea lions and humpback whales were found in shallower water over the continental shelf. SST was significant in predicting the presence of Dall's porpoise and the harbor porpoise: Dall's porpoise was found in relatively cooler water and the harbor porpoise in relatively warmer water. Wind speed was significant for all but California sea lions; as wind speed increased, the presence of the northern fur seal, the harbor porpoise, Dall's porpoise, the Pacific white-sided dolphin and the humpback whale decreased. The ability to detect small inconspicuous species such as smaller cetaceans and some pinnipeds is affected by wind speed (and sea state); some marine mammals may have been present during surveys with higher wind speeds, but may not have been detected.
Variables used for the principal component analysis (PCA) were depth of water and sigma- $t$, delta- $t$, SST, and wind speed. The presence of all mammals combined yielded 2 ocean habitat-factors that explained $68.4 \%$ of the variance observed (Table 4 ). Factor 1 $(38.42 \%)$ indicated that the presence of different species was dependent on water depth, depth of sigma- $t$ and thermocline strength (delta- $t$ ) values. Factor 2 $(29.95 \%)$ indicated that presence of mammals was dependent on SSTs and wind speed.

Factor scores, representing a suite of variables for each sighting of each species, were plotted (Fig. 7) and both factor scores were significantly different among dominant species (Factors 1 and 2: chi-square p < 0.001). Pairwise multiple-comparison tests indicated that the northern fur seal and Dall's porpoise factor scores were significantly different from the factor scores of all other species because these taxa occupied deeper waters. Northern fur seals were also found 
Table 4. Factor loadings for PCA Sigma- $t$ model habitat variables sampled during 1992-1998 surveys. *: ecologically significant variables interpreted as component loadings with absolute values $\geq 0.300$ (Tabachnick \& Fidell 1996). Abbreviations as in Table 3

\begin{tabular}{|lcc|}
\hline $\begin{array}{l}\text { Sigma- } t \\
\text { model }\end{array}$ & \multicolumn{2}{c|}{ Factor loadings } \\
\hline DPT & $0.785^{*}$ & 2 \\
SST & -0.042 & 0.077 \\
WSP & -0.266 & $0.900^{*}$ \\
DELTAT & $-0.689^{*}$ & $-0.644^{*}$ \\
SIGMAT & $0.870^{*}$ & $0.489^{*}$ \\
\% variance explained & 38.42 & 0.164 \\
\hline
\end{tabular}

where sigma- $t$ depths were deeper, SST was warmer, and wind speed was reduced, whereas Dall's porpoises were found in a range of ocean habitat conditions (cool and warm SSTs, reduced and higher wind speeds, high and low delta- $t$, and moderate to deep depths of sigma- $t$ ). California sea lions were found in a variety of SSTs; however, their occurrence differed from that of northern fur seals because they occurred in shallower water, shallower sigma- $t$, and stronger thermocline. Harbor porpoise were also found in shallower depths of water, warmer SSTs, reduced wind speed, shallower sigma- $t$, and stronger thermocline. Pacific white-sided dolphins and humpback whales were found where there were moderate depths of water and sigma- $t$ values, moderate SSTs and stronger thermocline (greater delta- $t$ values).

Mapped results of the surface and vertical structure overlaid with sighting locations supported the descriptive and multivariate statistical results. Comparisons of GIS-generated maps indicated distinct similarities and differences among and within years. For example, for the early-spring survey of 1993, mapped isotherms verified by composite AVHRR images indicated that no upwelling plumes were present, SSTs were relatively warm, and sighting rates were relatively low (5.6 sightings $\mathrm{km}^{-1}$ ). In contrast, during late spring of 1993 (El Niño), although SSTs were relatively warm (13.9 \pm $2.0^{\circ} \mathrm{C}$ ), isotherms and the AVHRR image indicated the presence of upwelling near Pt. Reyes and Pt. Año Nuevo. These features coincided with higher sighting rates (8.4 sightings $100 \mathrm{~km}^{-1}$ ).

During the late spring surveys (1992 to 1994, 1997 to 1999), sighting rates and mean upwelling indices were negatively correlated (Pearson correlation coefficient $=$ $-0.876, p=0.01 ; n=7$ ). Sighting rates were higher during relaxation of upwelling, as indicated by the presence of relatively cool upwelling plumes with stratified

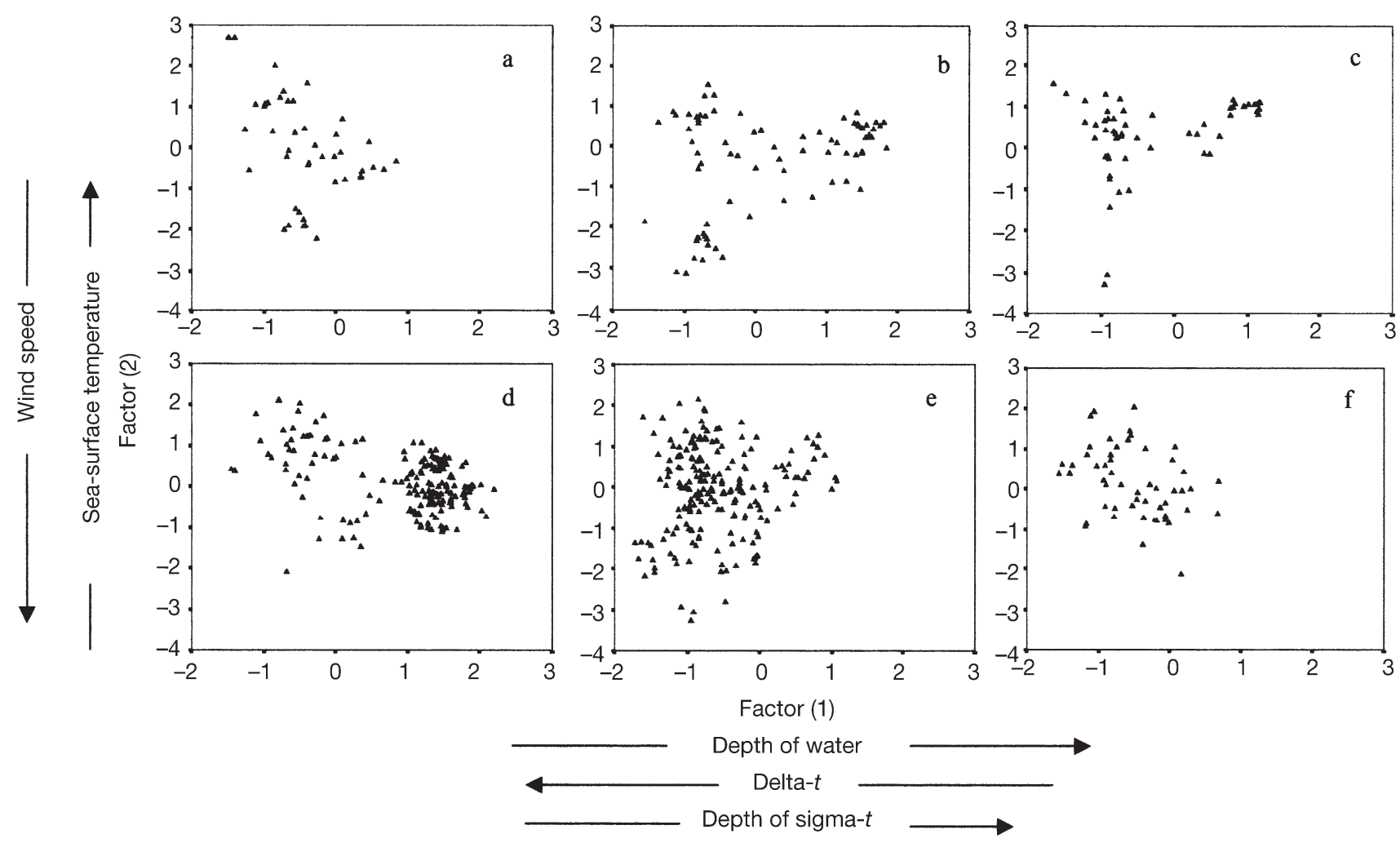

Fig. 7. Distribution of factor scores for (a) Pacific white-sided dolphin, (b) Dall's porpoise, (c) harbor porpoise, (d) northern fur seal, (e) California sea lion, and (f) humpback whale, defined by the factors of principal component analysis for 1992-1994 and 1997-1998 (combined data) 
Table 5. Summary of sighting rates (sightings $100 \mathrm{~km}^{-1}$ ) and number of sightings of marine mammals during 1992-1994 and $1997-1999$

$\left(^{*}\right.$ : El Niño years). 1999_1 \& 1999_3: Sweeps 1 \& 3 of 1999. Values in round parentheses are sighting rates for the numerically dominant species; those in square parentheses are the mean group size for the Pacific white-sided dolphin Lagenorhynchus obliquidens

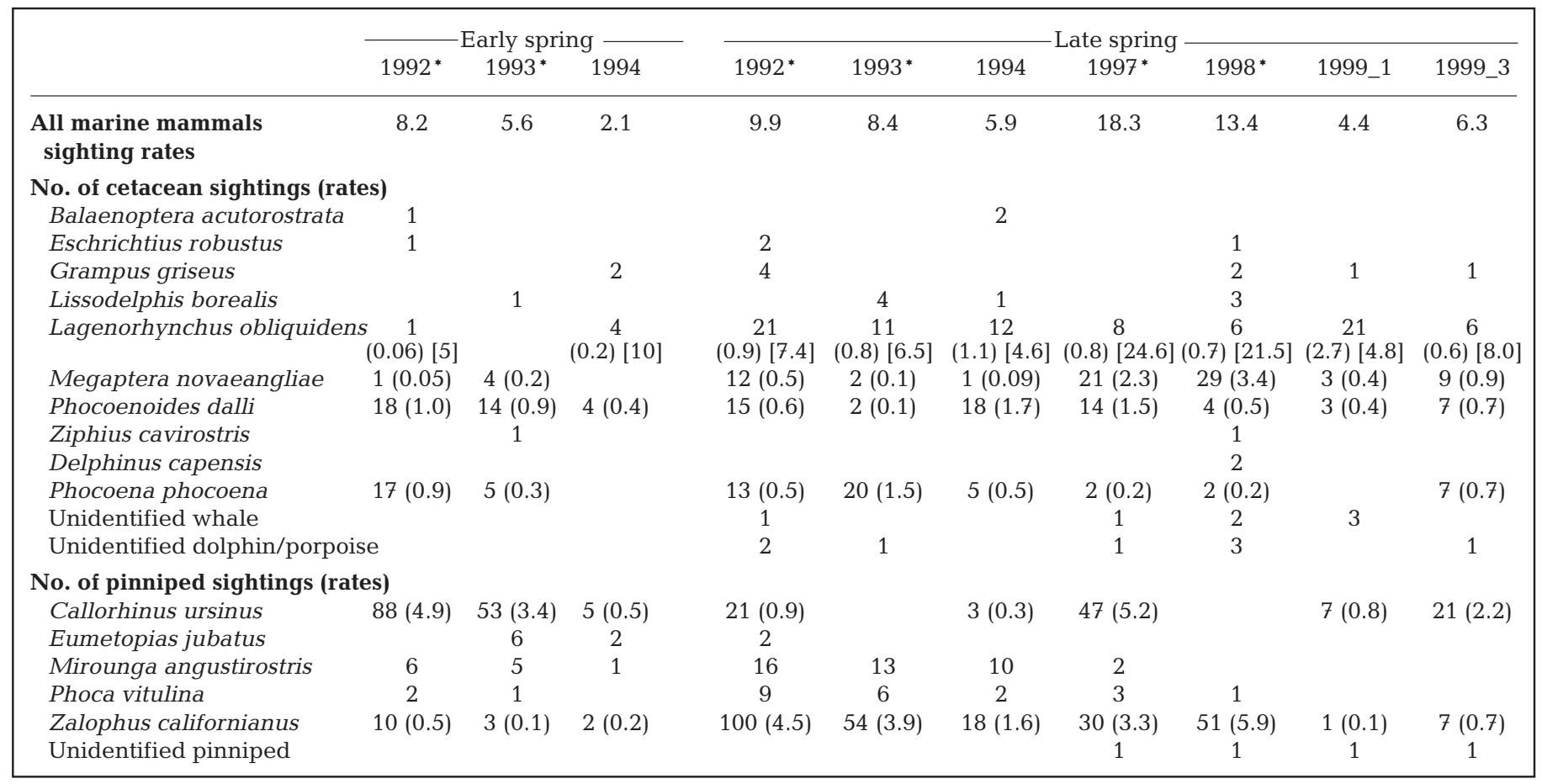

ocean conditions, and reflected in relatively warm SSTs, relatively strong, shallow thermocline and shallow sigma-t, and relatively low upwelling index values (Tables 1, 5 \& 6).

\section{Prey availability}

The species composition of mid-water trawls, frequency of occurrence (FO), catch per unit effort (CPUE), and mean catch per tow (Fig. 8) of the northern anchovy Engraulis mordax, the Pacific sardine Sardinops sagax, the Pacific hake Merluccius productus, rockfish Sebastes spp. and the market squid Loligo opalescens varied markedly among late-spring survey periods (Fig. 9). During 1993 and 1997, the relatively high CPUE coincided with higher sighting rates, reduced winds, relatively warmer water and wellstratified ocean conditions, whereas during 1994 and Sweep 1 of 1999, the relatively low CPUE coincided with lower sighting rates, stronger winds, relatively cooler SST and ocean conditions that were less stratified (Fig. 10). Although the CPUE was also low during Sweep 3 of 1999, an increase of 1.9 sightings km-1 and changes in species composition of marine mammals coincided with relatively warmer SSTs, a reduction in mean wind speed, and ocean structure that was more stratified than during Sweep 1 (Tables 1 \& 5).
Juvenile hake was the numerically dominant fish during 1993 and 1997, occurring in $>40 \%$ of hauls in 1993 and $70 \%$ of hauls in 1997 . However, the proportions and frequency of the occurrence of hake were also relatively high during 1994 and 1999, coincident with relatively low CPUE (<200 fish per haul), relatively cooler water and weakly stratified ocean conditions. The markedly reduced CPUE in the strong El Niño year (1998, when $50 \%$ of the total catch comprised sardines) coincided with warmer SSTs, a depressed thermocline and the second highest mammal sighting rates of all surveys. In cool-water years (1994 and 1999), no sardines were caught (1994) or proportions were $<10 \%$ (1999).

\section{DISCUSSION}

The high degree of temporal and spatial variability in marine mammal occurrence patterns reported herein is characteristic of the highly dynamic CCS. The distribution of marine mammals in the CCS is related to seasonal migrations, large-scale oceanographic events (El Niño/La Niña), and movements in response to warm- or cool-water conditions (Kajimura 1980, Bonnell et al. 1983, Dohl et al. 1983, Allen 1994, Black 1994, Barlow 1995, Calambokidis et al. 1996, 2000, Forney \& Barlow 1998, Forney 2000, Benson et al. 2002). As also noted in 
Table 6. Species designated 'other'. (a) Proportion of sightings during late spring surveys of mysticete, pinniped and odontocete species. (b) Values in first set of parantheses are number of sightings; those in second set are total number of individuals. Surveys 1 \& 3 of 1999 indicated by 1999_1 \& 1999_3. See Table 2 for explanation of species codes. ns: no surveys

\begin{tabular}{|c|c|c|c|c|c|c|c|c|c|c|c|c|c|c|c|}
\hline & 1986 & 1987 & 1988 & 1989 & 1990 & 1991 & 1992 & 1993 & 1994 & 1995 & 1996 & 1997 & 1998 & 1999_1 & 1999_3 \\
\hline \multicolumn{16}{|l|}{ (a) } \\
\hline Mysticete sp. & 0.05 & 0.02 & 0.00 & 0.08 & 0.01 & 0.00 & 0.01 & 0.00 & 0.03 & ns & ns & 0.01 & 0.03 & 0.09 & 0.02 \\
\hline Pinniped sp. & 0.16 & 0.18 & 0.17 & 0.08 & 0.27 & 0.19 & 0.14 & 0.18 & 0.06 & ns & ns & 0.10 & 0.03 & 0.03 & 0.02 \\
\hline Odontocete sp. & p. 0.09 & 0.13 & 0.00 & 0.10 & 0.02 & 0.07 & 0.03 & 0.05 & 0.02 & ns & ns & 0.03 & 0.07 & 0.06 & 0.02 \\
\hline \multicolumn{16}{|l|}{ (b) Species } \\
\hline DOCO & & & & (2) (77) & & & & & & & & & (2) (1300) & & \\
\hline DORW & & (6) (38) & & & & & (4) (18) & & (1) (5) & & & & (2) (28) & & \\
\hline DORI & (1) (2) & (1) (6) & & (3) $(70)$ & (1) (6) & (7) $(27)$ & (4) (10) & & & & & & & (1) (8) & (1) (15) \\
\hline DOLP & (9) (19) & & & & & & (2) (3) & (1) (1) & & & & & & & \\
\hline PORP & & & & & (1) (2) & & & & & & & (1) (1) & (1) (2) & & \\
\hline SEHA & (6) (8) & (2) (2) & (1) (1) & & (10) (10) & (5) (5) & (9) (9) & (7) (10) & (2) (2) & & & (3) (3) & (1) (1) & & \\
\hline SEAL & & & & & & & & & & & & (1) (1) & (1) (1) & (1) (1) & \\
\hline SENE & (12) (12) & (8) (8) & (4) $(4)$ & (5) (5) & (12) (12) ( & (13) (13) & (16) (17) & (13) (13) & & & & & (2) (2) & & \\
\hline SLNO & & & & & (3) (3) & (1) (1) & (6) (6) & (2) (2) & (2) (2) & & & & & & \\
\hline WHCU & & & & & & & & & & & & (1) (4) & & & \\
\hline WGRA & & & & & & & (2) (2) & & & & & & (1) (1) & & \\
\hline WHAL & & & & & & & & & & & & (1) (1) & (2) (2) & (3) (3) & (1) (2) \\
\hline WHBK & (1) (9) & & & (1) (10) & & & (1) (8) & & & & & & & & \\
\hline WMIN & (6) (6) & (1) (2) & & (3) (6) & (1) (1) & & & & (2) (2) & & & & & & \\
\hline WSEI & & & & (2) (2) & & & & & & & & & & & \\
\hline WKIL & & & & & & & & (1) (1) & & & & (2) (5) & (1) (4) & & \\
\hline
\end{tabular}
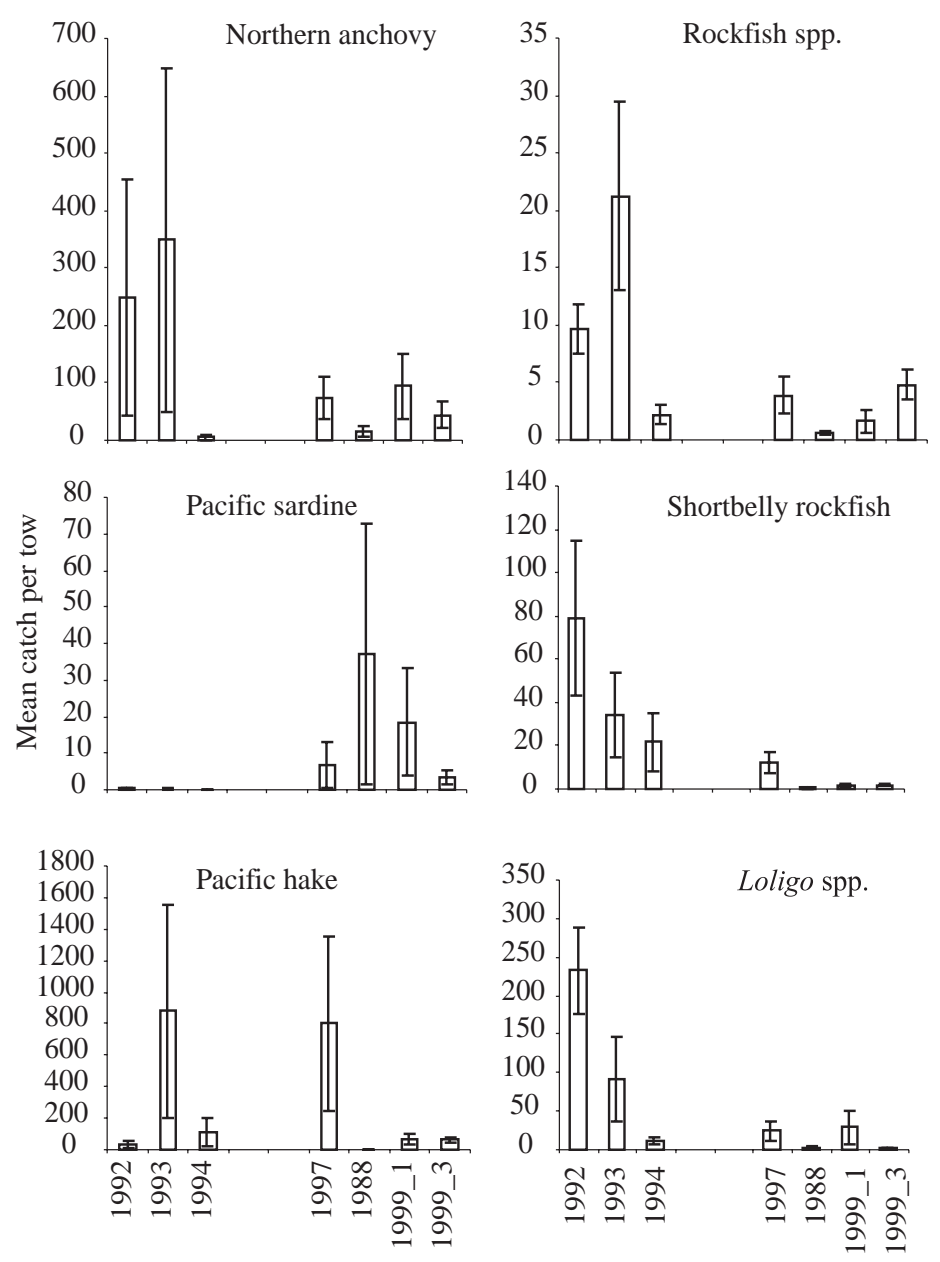

a number of studies, the distribution of prey availability varies from year to year (Larson et al. 1994, Lynn et al. 1998, Hayward et al. 1999, Chavez et al. 2002). Few researchers, however, have examined long-term seasonal and inter-annual changes in association with habitat features, and fewer still have attempted to relate variability, even indirectly, to changes in prey availability.

\section{Small-scale factors and processes}

\section{Ocean depth}

We found a strong relationship, consistent throughout the time span of the study, between the occurrence of abundant species and ocean depth

Fig. 8. Mean $( \pm$ SE) catch per haul of anchovy, sardine, hake, rockfish (Chilipepper Sebastes goodei, Brown Sebastes auriculatus, Widow Sebastes entomelas, Squarespot Sebastes hopkinsi, Canary Sebastes pinniger, Blue Sebastes mystinus, Stripetail Sebastes saxicola, Bocaccio Sebastes paucispinis, Yellowtail Sebastes flavidus, Halfbanded Sebastes semicinctus, Pygmy Sebastes wilsoni, Black Sebastes melanops, Olive Sebastes serranoides, Splitose Sebastes diploproa, Grass Setastes rastrelliger, Copper Sebastes caurinus), Shortbelly rockfish Sebastes jordani, and Loligo spp. in mid-water trawls conducted at night by NMFS Tiburon Laboratories during late-spring surveys. See Fig. 9 for total number of hauls conducted in each survey. Note differences in scale of ordinates. No sampling in 1995 and 1996. 1999_1 \& 1999_3: Sweeps 1 \& 3 of 1999 
(see also Dohl et al. 1983, Brueggeman et al. 1992, Kieckhefer 1992, Allen 1994, Black 1994, Yen et al. 2004). Thus, these results confirm those of previous, but usually short-term, studies. We found that Pacific white-sided dolphins, Dall's porpoise and northern fur seals were distributed along the shelf-break and seaward of the $200 \mathrm{~m}$ isobath (see also Black 1994). Dall's porpoise was also more concentrated near the Farallon Islands and Cordell Bank (35 km west of Pt. Reyes; Fig. 1). Humpback whales were distributed on the shelf and seaward of the $200 \mathrm{~m}$ isobath, whereas harbor porpoise were on the shelf in shallow waters. California sea lions were distributed on the shelf and along the shelf-break with concentrations near haul-out sites at Pt. Reyes, the Farallon Islands, and Pt. Año Nuevo (Allen 1994, Sydeman \& Allen 1999).

\section{Upwelling verses relaxation}

At the smallest temporal scale in our study (days), ocean conditions reflected wellknown oscillations between upwelling and relaxation (Send et al. 1987, Schwing et al. 1991, Rosenfeld et al. 1993). Upwellingfavorable winds strengthen and relax at 3 to $10 \mathrm{~d}$ (Schwing et al. 1991) or $20 \mathrm{~d}$ intervals (Baltz 1997), and multiple upwellingrelaxation events occur from approximately March to September. This is particularly evident in the comparison of upwelling indices before and during surveys in 1992 to 1994, and 1997 to 1999 (Fig. 11). For example, upwelling-favorable winds (relatively strong winds) and relatively greater upwelling indices before and during surveys (1994 and 1999) resulted in cooler SSTs, a relatively broad extension of the upwelling plumes, and relatively weak stratification that coincided with relatively low CPUE and lower sighting rates (Fig. 10). During the surveys of 1994 and 1999, the relatively strong winds that generate intense upwelling (and resultant high seas) presumably affected the probability of sighting the small, inconspicuous species (Barlow 1988, Barlow \& Forney 1994). For example, sightings of Dall's porpoise, the harbor porpoise, and the northern fur seal were low or zero during the relatively intense upwelling survey of 1999, when mean wind speed was $20 \pm 5.8$ knots.
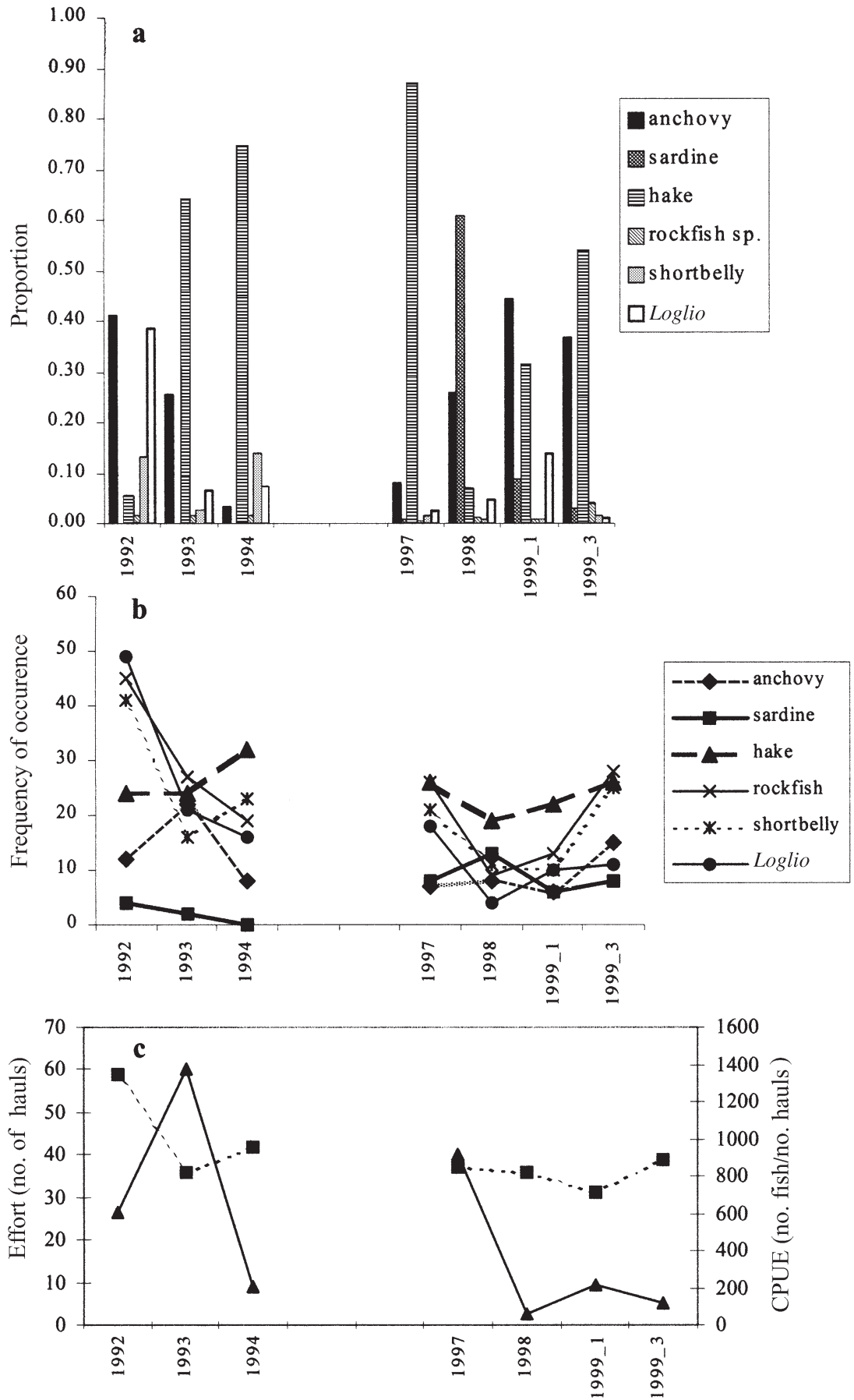

Fig. 9. (a) Proportion, (b) frequency (\%) of occurrence, (c) effort ( $\mathbf{\square}$ ) and catch per unit of effort $(\boldsymbol{\Lambda})$ of anchovy, sardine, hake, rockfish, shortbelly rockfish, and Loligo spp. in mid-water trawls conducted at night by NMFS Tiburon Laboratories during late spring survey periods. 1999_1 \& 1999_3: Sweeps 1 \& 3 of 1999

On the other hand, sighting rates increased during relaxation of upwelling, as evident in the comparison of upwelling indices before and during the surveys of 1993 and 1997 (Fig. 11), when the ocean habitat was characterized by a shallower thermocline depth and 
sigma- $t$, and stronger stratification (as indicated by greater vertical thermal gradients), lighter winds (improved sighting conditions) and a relative reduction in the extent of surface upwelling plumes. However, because the CPUE of potential prey also increased, the
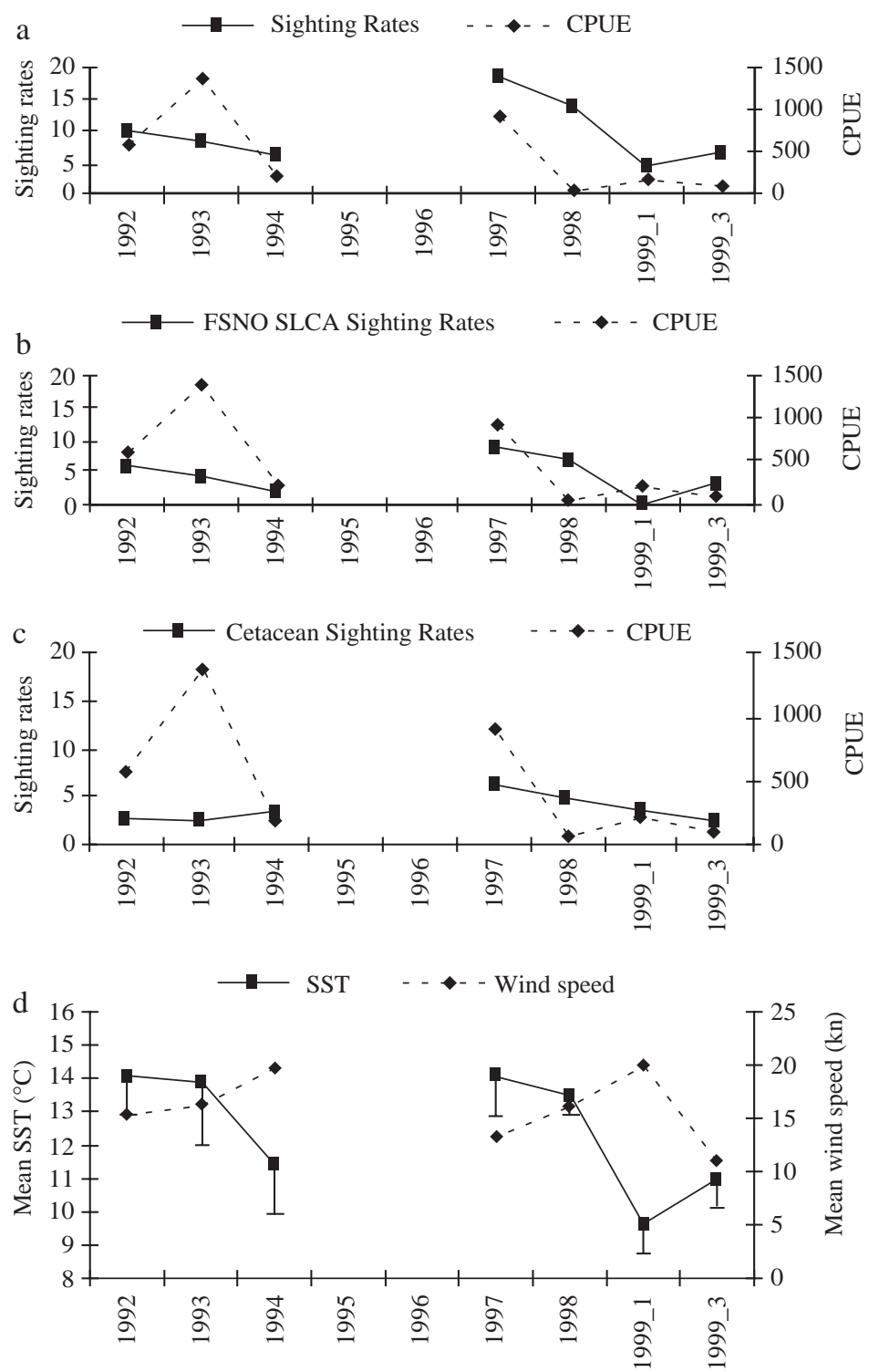

e $\square$ Mean Sigma- $t$ depth $\square$ Mean thermocline depth $\square$ Delta- $t$

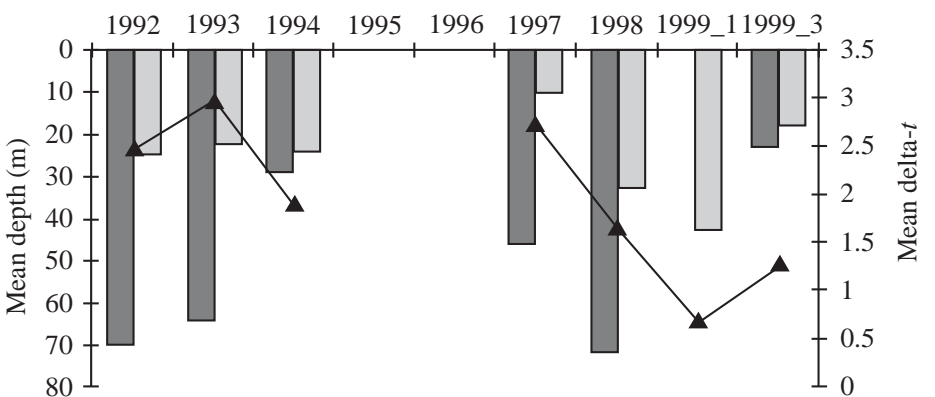

increase in the number of mammals seen was not entirely due to better sighting conditions (Figs. 10 \& 11). Although relaxation events produce nutrientrich water and can result in food-web development (Schwing et al. 1991, Rosenfeld et al. 1994, Parker 1996, Baltz 1997), these events also physically entrain, aggregate and stabilize prey resources in dynamic physical features (e.g. fronts and eddies) of upwelled water (Denman \& Powell 1984, Larson et al. 1994, Sakuma \& Ralston 1995, Gargett 1997). Upper-trophic-level marine predators might well respond to changes in physical features of the ocean that ultimately affect the distribution of marine mammal prey, due either to passive entrainment or behavioral changes (e.g. habitat selection in advected or retained upwelled water). During relaxation, when warm water flows poleward from the Gulf of the Farallones (the central portion of the study area), portions of the study region represent important retention areas for plankton and fish larvae (Wing et al. 1998). During relaxation or moderate upwelling, high chlorophyll coincides with greater larval fish abundances, coupled with medium to large adult biomass (Denman \& Powell 1984, Cury et al. 1995). Furthermore, Larson et al. (1994) found retention and onshore movement of all sizes of rockfish during relaxation events in the Gulf of the Farallones.

Surveys during late spring in 1993 and 1997 provided examples of the strong association between the relaxation of upwelling, more stable availability of prey resources (as indicated by greater CPUE), and greater sighting rates. Specifically, Pacific white-sided dolphins were sighted during both cool-water (and relatively intense upwelling) periods and warm-water (and reduced/relaxed upwelling) periods. This species is present year-round, but group size changes with season (Black 1994). Accordingly, we found a mean group size of 4.8 dol-

Fig. 10. Sighting rates (sightings $100 \mathrm{~km}^{-1}$ ) and catch per unit effort (CPUE) for (a) all mammals, (b) northern fur seal (FSNO) and California sea lion (SLCA) combined, and (c) cetaceans (humpback whale, harbor porpoise, Dall's porpoise and Pacific white-sided dolphin combined in mid-water trawls conducted at night by NMFS Tiburon Laboratories. (d) Mean wind speed and sea-surface temperature (SST); (e) mean sigma- $t$ depth, mean thermocline depth, and mean thermocline strength, delta- $t$. All data for late-spring surveys; standard deviations in Table 1. 1999_1 \& 1999_3: Sweeps 1 \& 3 of 1999 
phins per sighting during intense upwelling in 1999 (Sweep 1) in contrast to the 1997 warmer-water survey, when sighting rates were 0.8 sighting $100 \mathrm{~km}^{-1}$ and the mean group size was 24.6 dolphins per sighting (Table 5). The greater group size of these dolphins was coincident with greater trawl catches of squid and hake, which are known prey (Fiscus \& Niggol 1965, Morejohn et al. 1978, Jones 1981, Stroud et al. 1981, Black 1994). At the small scale, the relatively high variability in habitat variables associated with Pacific white-sided dolphin sightings may explain the non-significant PCA and logistic regression results. Variables strongly associated with presence of harbor porpoise (depth of water, sigma- $t$, delta- $t$, SST, and wind speed) indicated an association with warmer-water relaxation phases during 1992-1993 that also may have been related to availability of prey.

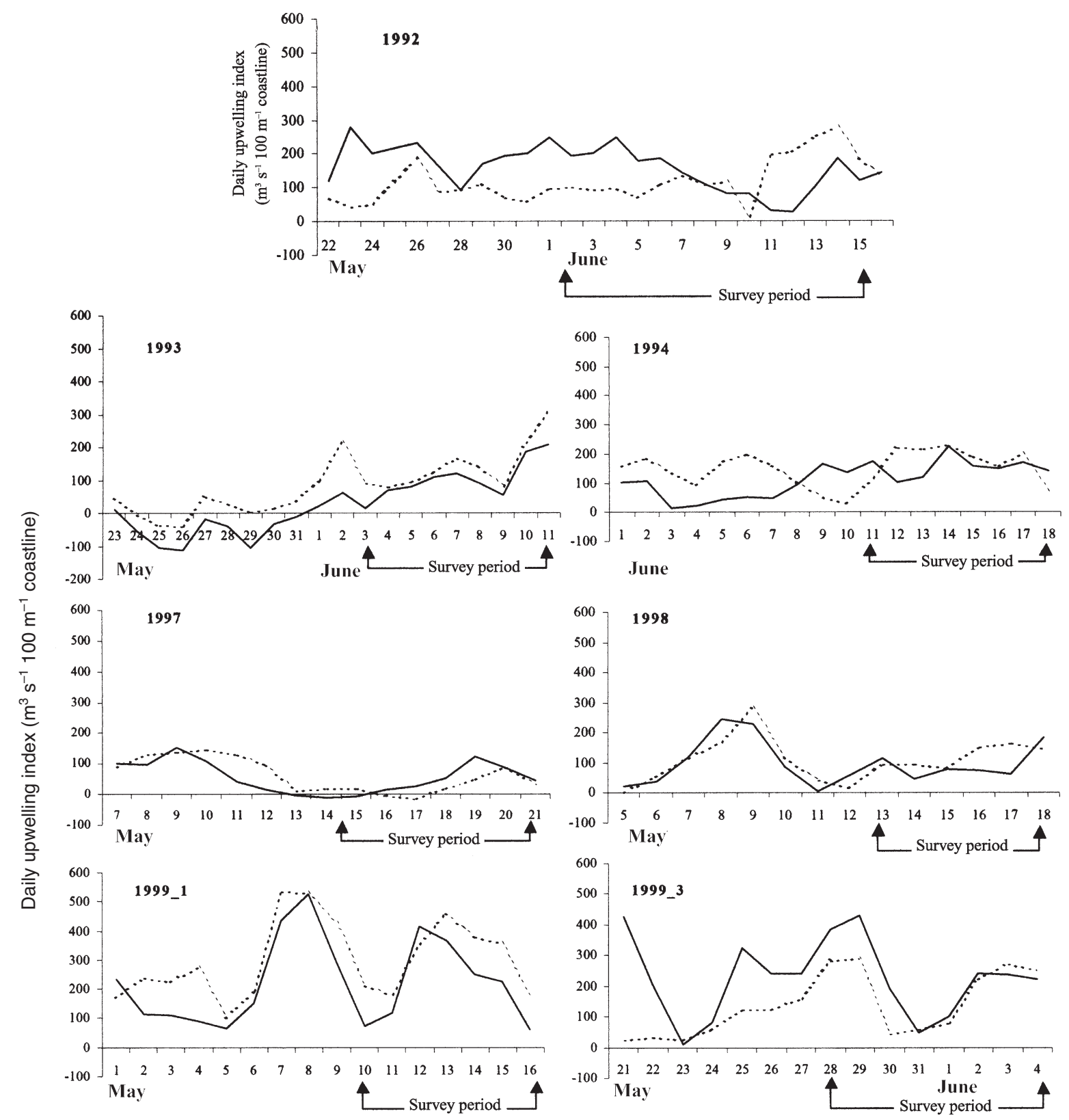

Fig. 11. Time series of daily upwelling index at $39^{\circ} \mathrm{N}, 125^{\circ} \mathrm{W}$ (continuous line) and $36^{\circ} \mathrm{N}, 122^{\circ} \mathrm{W}$ (dashed line) for May-June 1992-1994 and 1997-1999 indicating upwelling index before and during surveys north and south of survey area. 1999_1 \& 1999_3: Sweeps 1 \& 3 of 1999 


\section{Large-scale factors and processes}

\section{El Niño}

El Niño events that occurred during survey periods (1986-1987, 1992-1993, 1997-1998) varied in intensity and duration (Rasmusson \& Carpenter 1982, Wolter 1987, Wolter \& Timlin 1998). The variations in El Niño can have short-term (vertical/horizontal redistribution) and long-term (changes in abundance and species assemblages) effects on the availability of potential prey (Lenarz et al. 1995, Hayward et al. 1999) and in turn could affect mammal occurrence. For example, surveys conducted in 1997 and 1998 occurred just before and after one of the strongest El Niños since 1957. However, during its early stages in the spring of 1997, the El Niño impacts were small in the North Pacific (Lynn et al. 1998). Although marine mammal surveys during 1997 and 1998 were conducted during relaxation events when the ocean was more stratified, the ocean habitat was markedly different and conditions during these years were rather anomalous. During the 1997 survey, the upwelling index was the lowest of all late-spring surveys, the thermocline depth was the shallowest of all surveys, and delta- $t$ values were the second highest of all surveys. The greater sighting rates that occurred during this survey coincided with the second greatest CPUE of potential prey. Indeed, the greater sighting rates during this survey and the uniform presence/absence frequency distributions along tracklines (more uniform than clumped) were probably an indication of elevated ocean productivity.

In striking contrast, the ocean habitat during the 1998 survey reflected a local relaxation event coupled with large-scale effects of the strong El Niño. The thermocline and sigma- $t$ were the deepest of any survey, and vertical thermal gradients were weak. The spatial distribution of primary productivity at that time was limited to the shelf and near-shore coastal regions (Ralston et al. 1999, Chavez et al. 2002). The distribution of sardine eggs was also narrow and near the coast (and the overall abundance of macrozooplankton in February 1998 off southern California was the lowest in the 50 years of the CalCOFI time series (Lynn et al. 1998). Off central California, the lowest CPUE of all surveys (61 fish per haul) was observed during the spring of 1998, with low abundances of anchovy, sardine, hake, rockfish and squid.

Surprisingly, sighting rates during 1998 were the second highest of all surveys, a phenomenon that can be explained, in part, by the greater proportion of sightings of California sea lions and humpback whales. The greater numbers of California sea lions sighted during 1998 (and the 1992 to 1993 El Niño) probably reflected a greater than usual northward migration in response to a reduction in food resources near southern breeding grounds (Trillmich \& Ono 1991). Bonnell $\&$ Ford (1987) reported that in non-El Niño years, $18 \%$ of the population was probably at sea, whereas during El Niño, up to $54 \%$ of the population is at sea. Peak numbers of California sea lions also occurred on the Farallon Islands during the El Niño years of 1983, 1992, and 1997 to 1998 (Sydeman \& Allen 1999). Although SST was not strongly associated with the presence of California sea lions (logistic regression results), the plots of PCA factor scores indicated that this species was sighted in warmer SSTs, where thermoclines were either shallow or relatively deep. These conditions prevailed in the study area during relaxation events (1997) or El Niño years (1998).

The variability in humpback whale sightings, with higher numbers of sightings during 1997 to 1998 (and fewer sightings during other years), was consistent with the photographic identification studies of Calambokidis et al. (2000). Humpback whales along the California coast migrate from waters off Mexico and Central America and although they are sighted from the Farallon Islands (located in the study area; Fig. 1) in all months (Pyle \& Gilbert 1996), they are more frequently sighted off central California from March through November, with peaks in summer and fall (Calambokidis et al. 1996). Because there is a high degree of interchange of humpbacks within a feeding season among feeding regions off California, Oregon and Washington, and little interchange with feeding regions farther north (Calambokidis et al. 2001), the variability of sightings we observed is probably the result of changes in the movement patterns of these far-ranging animals. During 1998, a greater number of humpback whales was either moving through the study area en route to another part of the California coast, or was responding to localized prey patches that were limited to shelf and near-shore regions (Lynn et al. 1998, Ralston et al. 1999, Benson et al. 2002, Chavez et al. 2002). Near-shore studies in Monterey Bay revealed unique conditions during the 1998 El Niño that produced a narrow band of productivity near the coast (Benson et al. 2002, Chavez et al. 2002). The increase in humpback whale sighting rates (during 1997 to 1998) might also be due to an increase in the estimates of abundance off central California from 1991-1997 (Calambokidis \& Barlow 2004).

The striking differences in sightings of northern fur seals during the early to late spring surveys (1992 to 1993 and 1997 to 1998) observed in this study indicate that this species may have been responding to oceanographic changes associated with El Niño events. During autumn, adult female and juvenile northern fur seals migrate from breeding areas in the Bering Sea 
and the Sea of Okhotsk (Kenyon \& Wilke 1953, Kajimura 1980, Pyle et al. 2001) to continental slope waters off western North America (Antonelis \& Perez 1984, Kajimura 1982). Usually, the greatest numbers off central California occur during February to May (Kajimura 1982). A striking increase of northern fur seals was detected during the early spring 1992 to 1993 (El Niño), when greater catches of larval fishes and hake were reported offshore (Sakuma \& Ralston 1995). Fur seal sighting patterns may also have been affected by an increase in off-shore survey effort during 1992 to 1994, or by a change in sighting conditions. Because wind speed and upwelling indices during the early spring of 1994 were greater than those during 1992 to 1993, these conditions may have resulted in the under estimation of fur seals.

During the late-spring surveys, the greatest proportion of fur seal sightings $(>30 \%)$ and relatively high sighting rates (5.2 sightings $\mathrm{km}^{-1}$ ) occurred during late spring of 1997, a warm-water year. Although York (1991) found no significant association between SST and oceanic survival during the period that the fur seals are at sea during their first 4 yr, Kajimura (1979) suggested that the distribution and migration routes of young fur seals were strongly affected by ocean currents and prevailing wind regimes. During the 1997 survey, fur seal sightings coincided with warmer, wellstratified ocean conditions, and greater CPUE in trawls, with a predominance of hake, an important prey item (Kajimura 1982). In contrast, few fur seals were sighted during 1998, when CPUE was the lowest of all surveys with low proportions of Pacific hake. During 1997 and 1998, however, low pup production and high pup mortality were reported on San Miguel Island (DeLong \& Melin 1999) and on Bogoslof Island (Ream et al. 1999), and the effects of the 1997 to 1998 El Niño resulted in almost complete mortality of the 1997 cohort of northern fur seal. The absence of fur seals in the 1998 surveys, therefore, may have been the result of a decline in the total population. Patterns of occurrence of northern fur seals at sea were consistent with sightings of animals hauled out on the South Farallon Islands (Pyle et al. 2001).

The lower numbers of Dall's porpoise sightings during the warmer surveys of 1992 to 1993, and 1998 (El Niño years) are consistent with observations of other studies (Barlow \& Gerrodette 1996, Forney 2000). Dall's porpoises shift southward during cooler-water periods (Forney \& Barlow 1998), and the variability in sighting rates among survey periods observed during this study may have been attributable to such shifts. The highest numbers of sightings occurred during 1994 and 1997, coinciding with a relatively high CPUE for hake, an important prey item (Stroud et al. 1981). Although the highest number of sightings occurred in the 1994 cool-water upwelling period, this may have been due to a more extensive survey coverage in the cool-water plume area during this survey.

La Niña

During the 1999 upwelling season, La Niña conditions were evident along the entire coast, with upwelling anomalies among the greatest within the available 50 yr record of the upwelling index (Hayward et al. 1999, Bograd et al. 2000, Schwing et al. 2000). Indeed, during Sweeps 1 and 3 of 1999, upwelling was more intense (Fig. 11) than in all other late spring surveys. Ralston et al. (1999) reported the lowest SSTs in $17 \mathrm{yr}$ of observation within the Pt. Reyes plume during Sweep $1\left(\sim 7.5^{\circ} \mathrm{C}\right)$. In the survey area, the large $\left(6142 \mathrm{~km}^{2}\right)$ upwelling plume extended along the coast and coincided with relatively high winds, elevated upwelling-index values, weak stratification and low sighting rates. However, a marked reduction in upwelling just before Sweep 3 (Fig. 11), and the short Sweep 3 relaxation event ( 1 to 2 d) resulted in expected abrupt changes in ocean conditions (Schwing et al. 2000); warmer SSTs and more stratified ocean structure that coincided with a change in species composition and an increase of 1.9 sightings $\mathrm{km}^{-1}$.

\section{Summary and conclusions}

The long-term data sets involving hydrography, environmental variables and marine mammal sightings used in this study provide an integrated perspective of the temporal and spatial variability in marine mammal distribution and ocean habitats off central California. Fluctuations in pinniped and cetacean sightings coincided with periodic variations in upwelling and relaxation, both within a season and from year to year. Although distributions of the numerically dominant species were closely related to bathymetry, occurrence patterns were also related to changing local- and large-scale physical and biological conditions that seemed to influence prey abundance and availability.

The spatial limitations of this study (constrained by the NMFS gridded transects) precluded the fine-scale sampling of surface plumes and shelf-break fronts. More site-specific sampling near fronts (both surface and vertical) would provide important knowledge about the linkages between these physical features and the distributional patterns of marine mammals and their prey. The limited seasonal scope of this study (conducted only during early and late spring) prevented an understanding of the long-term seasonal 
effects of upwelling and marine mammal movements into and out of the study area. A wider temporal window of sampling would provide a more complete understanding of the biological effects of the upwelling process. This knowledge would provide valuable information about physical-biological linkages occurring at seasonal and decadal time scales.

Acknowledgements. Cruises were conducted on the National Oceanic and Atmospheric Administration (NOAA) RV 'The 'David Starr Jordan'. We thank C. Alexander, I. Gaffney, D. Hardesty, P. Pyle, P. Ryan and H. R. Nevins for their assistance at sea. We also thank D. Roberts, K. Sakuma, K. Baltz and S. Ralston, personnel of the National Marine Fisheries Service (NMFS) Santa Cruz (formerly Tiburon) Laboratories for assistance at sea and for the CTD and mid-water trawl data, and J. Adams from Moss Landing Marine Laboratories for assistance in extracting the CTD variables. We appreciate and thank S. Bros, M. McGowan. D. Hyrenbach and 5 anonymous reviewers for their helpful comments on this manuscript.

\section{LITERATURE CITED}

Ainley DG, Boekelheid RJ (1983) An ecological comparison of oceanic seabird communities of the South Pacific Ocean. Stud Avian Biol 8:2-23

Allen SG (1994) The distribution and abundance of marine birds and mammals in the Gulf of the Farallones and adjacent waters, 1985-1992. PhD dissertation, University of California, Berkeley, CA

Antonelis GA Jr, Perez MA (1984) Estimated annual food consumption by northern fur seals in the California Current. Calif Coop Ocean Fish Investig Rep 26:135-145

Aseltine-Neilson D, Bergen D, Erickson M, Haaker P and 11 others (2000) Review of some California fisheries for 1999: market squid, Dungeness crab, sea urchin, prawn, abalone, groundfish, swordfish and shark, ocean salmon, nearshore finfish, Pacific sardine, Pacific herring, Pacific mackerel, reduction, white seabass, and recreational. Calif Coop Ocean Fish Investig Rep 41:8-29

Baltz KA (1997) Ten years of hydrographic variability off central California during the upwelling season. MS thesis Naval Postgraduate School, Monterey, CA

Barlow J (1988) Harbor porpoise, Phocoena phocoena, abundance estimation for California, Oregon, and Washington: Part I: Ship surveys. Fish Bull US Dep Comm 86:417-431

Barlow J (1995) The abundance of cetaceans in California waters. Part 1: Ship surveys in summer and fall 1991. Fish Bull US Dep Comm 93:1-14

Barlow J, Forney KA (1994) An assessment of the 1994 status of harbor porpoise in California. NOAA Tech Memo NMFS-SWFSC-205:1-17

Barlow J, Gerrodette T (1996) Abundance of cetaceans in California waters based on 1991 and 1993 ship surveys. NOAA Tech Memo NMFS SWFSC-233:1-15

Benson SR, Croll DA, Marinovic BB, Chavez FP, Harvey JT (2002) Changes in the cetacean assemblages of coastal upwelling ecosystem during El Niño 1997-98 and La Niña 1999. Prog Oceanogr 54:279-291

Black NA (1994) Behavior and ecology of Pacific white-sided dolphins (Lagenorhynchus obliquidens) in Monterey Bay, California. MS thesis, Moss Landing Marine Laboratories, San Francisco State University, CA
Bograd SJ, DiGiaccomo PM, Durazo R, Hayward TL and 8 others (2000) The state of the California Current, 1999-2000: forward to a new regime? Calif Coop Ocean Fish Investig Rep 41:26-52

Bonnell ML, Ford RG (1987) California sea lion distribution: a statistical analysis of aerial transect data. J Wildl Manag 51:13-20

Bonnell ML, Pierson MO, Farrens GD (1983) Pinnipeds and sea otters of central and northern California, 1980-1983: status, abundance and distribution. Final report prepared for the Pacific OCS Region Minerals Management Service, contract 14-12-00. Center for Marine Studies, University of California, Santa Cruz, CA

Breaker LC, Mooers CNK (1986) Oceanic variability off the central California coast. Prog Oceanogr 17:61-135

Brink KH (1983) The near-surface dynamics of coastal upwelling. Prog Oceanogr 12:223-257

Brueggeman JJ (1992) Oregon and Washington marine mammal and seabird surveys. Final report by Ebasco Environmental, Bellevue, WA and Ecological Consulting, Portland, OR for the Minerals Management Service, Pacific OCS Region OCS Study MMNS 91-0093

Calambokidis J, Barlow J (2004) Abundance of blue and humpback whales in the eastern North Pacific estimated by capture - recapture and line-transect methods. Mar Mamm Sci 20:63-85

Calambokidis J, Steiger GH, Cubbage JC, Balcomb KC, Bloedel P (1989) Biology of humpback whales in the Gulf of the Farallones. Final Report to the Gulf of the Farallones National Marine Sanctuary/NOAA. Cascadia Research Collective, Olympia, WA

Calambokidis J, Steiger GH, Evenson JR, Kieckhefer TR, Balcomb KC, Claridge DE (1991) Research on humpback and blue whales in the Gulf of the Farallones and adjacent waters. Final Report to the Gulf of the Farallones National Marine Sanctuary, NOAA, San Francisco, Cascadia Research Collective, Olympia

Calambokidis J, Steiger GH, Evenson JR, Flynn KR and 11 others (1996) Interchange and isolation of humpback whales off California and other north Pacific feeding grounds. Mar Mamm Sci 12:215-226

Calambokidis J, Steiger GH, Rasmussen K, Urban JHR and 8 others (2000) Migratory destinations of humpback whales that feed off California, Oregon and Washington. Mar Ecol Prog Ser 192:295-304

Calambokidis J, Steiger GH, Straley JM, Herman LM and 19 others (2001) Movements and population structure of humpback whales in the North Pacific. Mar Mamm Sci 17: 769-794

Chavez FP (1996) Forcing and biological impact of the onset of the 1992 El Niño in central California. Geophys Res Letters 23:265-268

Chavez FP, Pennington TJ, Castro CG, Ryan JP and 6 others (2002) Biological and chemical consequences of the 1997-98 El Niño in central California waters. Prog Oceanogr 54:205-232

Chelton DB, Bernstein RL, Bratkovich A, Kosro PM (1987) The central California coastal study. EOS Trans Am Geophys Un 68:1273

Croll DA, Tershy BR, Hewitt R, Demer D, Hayes S, Fiedler P, Popp J, Lopez VL (1998) An integrated approach to the foraging ecology of marine birds and mammals. Deep-Sea Res II (45):1353-1371

Cury P, Roy C, Mendelssohn R, Bakun A, Husby DM, Parrish $\mathrm{RH}$ (1995) Moderate is better: exploring nonlinear climatic effects on the Californian northern anchovy (Engraulis mordax). Can Spec Publ Fish Aquat Sci 121:417-424 
Day RW, Quinn GP (1989) Comparisons of treatments after an analysis of variance in ecology. Ecol Monogr 59:433-463

DeLong RL, Melin SR (1999) Population monitoring studies of northern fur seals at San Miguel Island, California. NOAA Tech Memo NMFS-AFSC-69:73-80

Denman KL, Powell TM (1984) Effects of physical processes on planktonic ecosystems in the coastal ocean. Oceanogr Mar Biol Annu Rev 22:125-168

Dohl TP, Guess RC, Duman M, Helm RC (1983) Cetaceans of central and northern California: status, abundance, and distribution Final Report for Minerals Management Service Contract 14-12-0001-29090, OCS Study MMS 84-0044. Center for Marine Studies, University of California, Santa Cruz, CA

Fiedler PC, Reilly SB, Hewitt RP, Demer D and 6 others (1998) Blue whale habitat and prey in the California Channel Islands. Deep-Sea Res II 45:1781-1801

Fiscus $\mathrm{CH}$, Niggol K (1965) Observations of cetaceans off California, Oregon, and Washington. US Fish Wildl Serv Spec Sci Rep Fish 498

Forney KA (2000) Environmental models of cetacean abundance: Reducing uncertainty in population trends. Conserv Biol 14:1271-1286

Forney KA, Barlow J (1998) Seasonal patterns in the abundance and distribution of California cetaceans, 1991-1992. Mar Mamm Sci 14:460-489

Fowler J, Cohen L, Jarvis P (1998) Practical statistics for field biology, 2nd edn. John Wiley \& Sons, Chichester

Gargett AE (1997) The optimal stability 'window': a mechanism underlying decadal fluctuations in North Pacific salmon stocks? Fish Oceanogr 6:109-117

Griffith DA (1987) Spatial autocorrelation; a primer. Association of American Geographers, Washington, DC

Hayward TL (1993) Preliminary observations of the 1991-1992 El Niño in the California Current. Calif Coop Ocean Fish Investig Rep 34:21-29

Hayward TL, Baumgartner TR, Checkley DM, Durazo R and 8 others (1999) The state of the California Current in 1998-1999: transition to cool-water conditions. Calif Coop Oceanic Fish Invest Rep 40:29-61

Heinemann D (1981) A range finder for pelagic bird censusing. J Wildl Manag 45:489-493

Horne JK, PE Smith (1997) Space and time scales in Pacific hake recruitment processes: latitudinal variation over annual cycles. Calif Coop Ocean Fish Investig Rep 38: 90-102

Huber HR, Ainley DG, Morrell SH (1980) Sightings of cetaceans in the Gulf of the Farallones. Calif Fish Game 68:183-18

Husby DM, Nelson CS (1982) Turbulence and vertical stability in the California Current. Calif Coop Ocean Fish Investig Rep 23:113-129

Huyer A (1983) Coastal upwelling in the California Current system. Prog Oceanogr 12:259-284

Huyer A, Kosro PM, Fleischbein J, Ramp S, Stanton T, Washburn L, Chavez F, Cowles T (1990) Currents and water masses of the coastal transition zone off northern California, June to August 1988. J Geophys Res 96:14809-14831

Jones RE (1981) Food habits of smaller marine mammals from northern California. Proc Calif Acad Sci 42(16):409-433

Kajimura H (1979) Fur seal pup/yearling distribution in the eastern North Pacific: In: Kajimura H, Lander RH, Perez MA, York AE, Bigg MA (eds) Preliminary analysis of pelagic fur seal data collected by the United States and Canada during 1958-74, NMFS. National Marine Mammal Laboratory, Seattle, WA, p 9-50

Kajimura H (1980) Distribution and migration of northern fur seals (Callorhinus ursinus) in the Eastern Pacific. In: Kajimura H, Lander RA, Perez MA, Yor AE (eds) Further analysis of pelagic fur seal data collected by the United States and Canada during 1958-74, Part 1. NMFSNWAFC, National Marine Mammal Laboratory, Seattle, WA, $\mathrm{p} 4-43$

Kajimura H (1982) Opportunistic feeding of the northern fur seal, Callorhinus ursinus, in the Eastern North Pacific and Eastern Bering sea. PhD dissertation, University Tokyo, Tokyo

Kelly DA (1985) The influence of winds and topography on the sea surface temperature patterns over the northern California slope. J Geophys Res 90:11783-11798

Kenyon KW, Wilke F (1953) Migration of the northern fur seal, Callorhinus ursinus. J Mammal 34:86-98

Kieckhefer TR (1992) Feeding ecology of humpback whales in continental shelf waters near Cordell Bank, California. MS thesis, Moss Landing Marine Laboratories, San Jose State University, CA

Larson RJ, Lenarz WH, Ralston S (1994) The distribution of pelagic juvenile rockfish of the genus Sebastes in the upwelling region off central California. Calif Coop Ocean Fish Investig Rep 35:175-219

Leatherwood S, Perrin WF, Kirby VL, Hubbs CL, Dahlheim M (1980) Distribution and movements of Risso's dolphin (Grampus griseus) in the eastern North Pacific. Fish Bull Fish US Dep Comm 77:951-963

Lenarz WH, Larson RJ, Ralston S (1991) Depth distributions of late larvae and pelagic juveniles of some fishes of the California Current. Calif Coop Ocean Fish Investig Rep 32:41-46

Lenarz WH, Ven Tresca D, Graham WM, Schwing FB, Chavez F (1995) Exploration of El Niños and associated biological population dynamics off central California. Calif Coop Ocean Fish Investig Rep 36:106-119

Lynn RJ, Baumgartner T, Garcia J, Collins CA and 8 others (1998) The state of the California Current, 1997-1998: transition to El Niño conditions. Calif Coop Ocean Fish Invest Rep 39:25-49

Morejohn GV, Harvey JT, Krasnow LT (1978) The importance of Loligo opalescens in the food web of marine vertebrates in Monterey Bay, California. Fish Bull Calif 169:67-98

Parker HA (1996) Variations in coastal circulation off central California, spring-summer 1993, 1994, 1995. MS thesis, Naval Postgraduate School, Monterey, CA

Pyle P, Gilbert L (1996) Occurrence patterns and trends of cetaceans recorded from southeast Farallon Island, California, 1973 to 1994. Northwest Nat 77:1-8

Pyle P, Long DL, Schonewald J (2001) Historical and recent colonization of the South Farallon Islands, California, by northern fur seals (Callorhinus ursinus). Mar Mamm Sci 17:397-402

Ralston S, Roberts D, Sakuma KM, Woodbury DP (1999) From El Niño to La Niña in the Gulf of the Farallones. EOS, Trans Am Geophys Un 80:565-566

Ramp SR, McClean JL, Collins CA, Semtner AJ, Hays KAS (1997) Observations and modeling of the 1991-1992 El Niño signal off central California. J Geophys Res 102(C3): $5553-5582$

Rasmusson EG, Carpenter TH (1982) Variations in tropical sea surface temperature and surface wind fields associated with the Southern Oscillation/El Niño. Mon Weather Rev Am Meteorol Soc 110:354-384

Ream RR, Baker JD, Towell RG (1999) Bogoslof Island studies, 1998. NOAA Tech Memo NMFS AFSC-69:81-91

Reilly SB, Fiedler PC (1994) Interannual variability of dolphin habitats in the eastern tropical Pacific. I: research vessel 
surveys, 1986-1990. Fish Bull US Dep Comm 92:434-450

Reilly SB, Thayer VG (1990) Blue whale (Balaenoptera musculus) distribution in the eastern tropical Pacific. Mar Mamm Sci 6:265-277

Rosenfeld LK, Schwing FB, Garfield N, Tracy DE (1993) Bifurcated flow from an upwelling center: a cold water source for Monterey Bay. Cont Shelf Res 14:931-964

Sakuma KM, Ralston S (1995) Distributional patterns of late larval groundfish off central California in relation to hydrographic features during 1992 and 1993. Calif Coop Ocean Fish Investig Rep 36:179-192

Sakuma KM, Schwing FB, Baltz K, Roberts D, Parker HA, Ralston S (1996) The physical oceanography off the central California coast during May-June 1995: a summary of CTD data from pelagic juvenile rockfish surveys. NOAA Tech Memo TM-NMFS-SWFSC-232

Saunders MW, GA McFarlane (1997) Observations on the spawning distribution and biology of offshore Pacific hake (Merluccius productus). Calif Coop Ocean Fish Investig Rep 38:147-157

Schoenherr JR (1991) Blue whales feeding on high concentrations of euphausiids around Monterey submarine canyon. Can J Zool 69:583-594

Schwing FB, Husby DM, Garfield N, Tracy DE (1991) Mesoscale oceanic response to wind events off central California in Spring 1989: CTD surveys and AVHRR imagery. Calif Coop Ocean Fish Investig Rep 32:47-62

Schwing FB, Hayward TL, Sakuma KM, Murphree T and 7 others (1997) The state of the California Current, 1996-1997: mixed signals from the tropics. Calif Coop Ocean Fish Investig Rep 38:22-47

Schwing FB, Moore CS, Ralston S, Sakuma KM (2000) Record coastal upwelling in the coastal ocean dynamics experiment. J Geophys Res 92(C2):1683-1698

Send U, Beardsley RC, Winant CD (1987) Relaxation from upwelling in the coastal ocean dynamics experiment. J Geophys Res 92(C2):1683-1698

Silver MW (1975) The habitat of Salpa fusiformis in the California Current as defined by indicator assemblages. Limnol Oceanogr 20:230-237

Smith RC, Dustan R, Au D, Baker KS, Dunlap EA (1986) Distribution of cetaceans and sea-surface chlorophyll concentrations in the California Current. Mar Biol 91:385-402

Smith RL (1992) Coastal upwelling in the modern ocean. In: Summerhayes CP, Prell WL, Emeis KC (eds) Upwelling systems: evolution since the early Miocene. Spec Publ

Editorial responsibility: Otto Kinne (Editor-in-Chief), Oldendorf/Luhe, Germany
Geol Soc Land 64:9-28

Stroud RK, Fiscus CH, Kajimura H (1981) Food of the Pacific white-sided dolphin, Lagenorhynchus obliquidens, Dall's porpoise, Phocoenoides dalli, and northern fur seal, Callorhinus ursinus, off California and Washington. Fish Bull Calif 78:951-959

Sverdrup HU, Johnson MW, Fleming RH (1942) The oceans: their physics, chemistry and general biology. PrenticeHall, Englewood Cliffs, NJ

Sydeman WJ, Allen SG (1999) Pinniped population dynamics in central California: Correlations with sea surface temperature and upwelling indices. Mar Mamm Sci 15: 446-461

Tabachnick BG, Fidell LS (1996) Using multivariate statistics, 3rd edn. Harper Collins College Publishers, New York

Tasker ML, Jones PH, Dixon T, Blake BF (1984) Counting seabirds at sea from ships: a review of methods employed and a suggestion for a standardized approach. Auk 101: $567-577$

Traganza ED, Conrad JC, Breaker LC (1981) Satellite observations of a cyclonic upwelling system and giant plume in the California current. In: Richards FA (ed) coastal upwelling. America Geophysical Union, Washington, DC

Trillmich F, Ono KA (eds) (1991) Pinnipeds and El Niño: responses to environmental stress. Springer-Verlag, Berlin

Wing SR, Botsford LW, Ralston SV, Largier JL (1998) Meroplanktonic distribution and circulation in a coastal retention zone of the Northern California upwelling system. Limnol Oceanogr 43:1710-1721

Wolter K (1987) The Southern Oscillation in surface circulation and climate over the tropical Atlantic, Eastern Pacific, and Indian Oceans as captured by cluster analysis. J Clim Appl Meteorol 26:540-558

Wolter K, Timlin MS (1998) Measuring the strength of ENSO-how does 1997/98 rank? Weather 53:315-324

Yen PPN, Sydeman WJ, Hyrenbach KD (2004) Marine bird and cetacean associations with bathymetric habitats and shallow-water topographies: implications for trophic transfer and conservation. J Mar Syst 50:79-99

York AE (1991) Sea surface temperatures and their relationship to the survival of juvenile male northern fur seals from the Pribilof Islands. In: Trillmich F, Ono KA (eds) Pinnipeds and El Niño: responses to environmental stress. Springer-Verlag, Berlin, p 94-106

Zar JH (1984) Biostatistical analysis, 2nd edn. Prentice-Hall, Englewood Cliffs, NJ

Submitted: November 19, 2002; Accepted: June 3, 2004

Proofs received from author(s): March 11, 2005 